\title{
THE ORGANIZATIONAL AND ECONOMIC MECHANISM OF IMPLEMENTING THE CONCEPT OF GREEN LOGISTICS
}

\author{
Henryk Dzwigol, Nataliia Trushkina, and Aleksy Kwilinski
}

\begin{abstract}
The article analyses the preconditions for shaping and developing the concept of a green economy. The stages of the evolutionary development of the circular economy are considered: work with waste; environmental performance strategies; maximum conservation in the era of resource depletion. Having analysed the scientific opinions on the emergence of "circular economy", the paper has found out that this concept is identified with the terms "round economy", "cyclical economy", "recovery economy", "closed-cycle economy", "green economy". The approaches of different scientific schools to the category of "circular economy" are analysed and conventionally systematized into 12 groups: closed-cycle economy; renewable resource economy; alternative to traditional linear economy; global economic model; closed-loop economic system based on R-principles; the concept of economic development; sustainable development strategy; a "green" economy instrument; business philosophy; economic activity; use of production waste; recycling of secondary raw materials. There is proposed the authors' formulation of the circular economy as an innovative approach to organizing logistics processes based on the closed movement of resources with their minimum losses in the form of waste and the maximum involvement of secondary resources in production in order to achieve sustainable development of logistics systems. The article identifies the barriers preventing the implementation of the circular economy concept, among them being regulatory, institutional, economic, financial and investment, market, technological, informational, and cultural. The article considers the best practices of effective implementation of circular economy solutions on the example of Finland. The indicators of the development of the green technologies market in the world and the national logistics system of Ukraine under conditions of a circular economy are analysed. It has been established that many conceptual approaches to the definition of the terms "green logistics" and "environmental logistics" are generally accepted and have a broader meaning, without taking into account the functioning specificity of various spheres of economic activity, including transport and logistics. Scientific views on interpreting the essence and content of the concept "green logistics" are generalized. It is proposed to consider the term "green logistics" from three angles: a circular economy instrument; a component of business corporate social responsibility; and a type of economic activity aimed at reducing the negative impact on the ecosystem and the environment. In order to effectively implement the concept of green logistics, an organizational and economic mechanism has been developed, the main elements of which are: diagnostics of the current state, features and trends in the logistics systems' development, taking into account the environmental component; exogenous and endogenous factors affecting the development of logistics systems; risks in organizing the processes of logistics activities; subjects and objects of management, goals, objectives,
\end{abstract}


principles, functions, tools, methods, management tools, information technology, criteria. The priority principles of forming an organizational and economic mechanism include consistency, integration, reliability, dynamism, compliance with the goals of sustainable development, and efficiency. A structural diagram of forming an organizational and economic mechanism for implementing the concept of green logistics is proposed, including the following blocks: management of material resources' supplies and purchases; products manufacturing; warehousing and stocks; logistic flows; the risks of logistics activities; logistics service processes; recycling of waste; innovation and transformations. Introduction of the proposed organizational and economic mechanism will reduce the cost of managing the movement of logistics flows and increase the level of environmental safety. This is one of the most important requirements for implementing the concept of business corporate social responsibility in a circular economy.

Keywords: green economy, circular economy, green logistics, environmental logistics, greening of logistics activities, green technologies, logistics system, conceptual approach, organizational and economic mechanism, components of the mechanism, information technology, efficiency, sustainable development, cost minimization, environmental safety.

JEL Classification: L86, Q20, R40 


\section{Author(s):}

Henryk Dzwigol

Silesian University of Technology, 26-28 Roosevelt Street, Zabrze, Poland, 41-800

E-mail: henryk.dzwigol@poczta.fm

https://orcid.org/0000-0002-2005-0078

\section{Nataliia Trushkina}

Institute of Industrial Economics of the National Academy of Sciences of Ukraine, Zheliabov St., 2, Kyiv, Ukraine, 03057

E-mail:nata_tru@ukr.net

https://orcid.org/0000-0002-6741-7738

\section{Aleksy Kwilinski}

The London Academy of Science and Business, 120 Baker Street, London, United Kingdom, W1U 6TU E-mail:a.kwilinski@london-asb.co.uk

https://orcid.org/0000-0001-6318-4001

Citation: Dzwigol, H., Trushkina, N., \& Kwilinski, A. (2021). The Organizational and Economic Mechanism of Implementing the Concept of Green Logistics. Virtual Economics, 4(2), 41-75. https://doi.org/10.34021/ve.2021.04.02(2)

Received: January 12, 2021. Revised: January 29, 2021. Accepted: March 24, 2021.

(C) Author(s) 2021. Licensed under the Creative Commons License - Attribution 4.0 International (CC BY 4.0) 


\section{Introduction}

Ensuring sustainable development of logistics systems requires introduction of organizational, managerial and environmental technologies adequate to transformational changes, as well as innovative models to reduce the negative impact of transport on the environment. This is in line with the green growth concept proposed by the Organization for Economic Cooperation and Development. As international experience shows, improving the efficiency of the transport sector and organizing logistics activities can be achieved through implementing conceptually new management tools based on the principles of logistics, namely, systematic, process approaches, concepts of "lean" production, "just in time," sustainable development (Abazov 2021; Dalevska et al. 2019; Dyduch 2019; Dzwigol 2019; 2020a; 2020b; Dzwigol \& Dźwigoł-Barosz 2018; 2020; Dzwigol et al. 2019a; 2019b; 2020a; 2020b; Kharazishvili et al. 2020; Lyulyov et al. 2021).

Today, leading scientists are conducting scientific discussions on implementing the concept of green growth in order to preserve the environment and improve the economic activities of enterprises. The desire of companies to create an ecological image with consumers has contributed to developing a sustainable logistics concept (Boichuk \& Kauf 2019) that includes green components and considers economic, social and environmental activities in the context of logistics management.

It is the greening of logistics activities that is a key vector for business development, since most consumers consider priority those companies that carry out cargo transportation by "green" transport and use technologies that conserve natural resources. The use of "green" technologies in logistics has become as much a necessity as the implementation of a quality management system. As a consequence, according to "the Green Trends Survey" in the study "Towards Sustainable Logistics" (Christof \& Ehrhart 2012), 59\% of businesses found out that green transportation of their products was recognized as a decisive factor in attracting consumers. Based on a survey by PE International (Great Britain) (McKinnon et al. 2010), there are identified the key advantages of implementing the green logistics concept which include the reduction of air emissions (33\% of heads and top managers of companies); attracting new customers, or developing new products ( $26 \%$ of respondents).

Thus, modern business conditions dictate new requirements for business development. The priority is green logistics as one of the most important components of the overall strategy of business social responsibility in the context of the circular economy development. It should be noted that the role and importance of green logistics as a tool to support environmental safety is becoming more relevant every year, since it has become a socially useful and profitable symbiosis of ecology and economics as a part of corporate environmental governance policies. 


\section{Literature review}

The term "green economy" was first mentioned in 1989 in a report by a group of leading economists to the government of the United Kingdom of Great Britain and Northern Ireland (Pearce et al. 1989).

This concept entered wide circulation during the global economic crisis of 2008-2009. In 2009, the UN Environment Program published the report "Global Green New Deal", which considered the goals, objectives, elements, incentives and directions of domestic policy aimed at developing a green economy. The green economy has mainly been defined as a practical approach to achieve sustainable development.

Currently, the concept of a green economy is being actively discussed by scientists, experts, business and public organizations. UNEP experts (2011) define a green economy as an economy that leads to improved human well-being and social justice and the same time significantly reduces environmental risks and ecological scarcity. According to this concept, the priorities of a green economy are, on the one hand, the maintenance and restoration of a natural capital, the use of renewable energy and low-carbon technologies for fossil fuels, an increase in the efficiency of resource and energy use, the formation of responsible behaviour of urban residents, the transition to low-carbon mobility, and on the other, creating new jobs and increasing social justice.

In the last decade, a new concept of economic development, called the "circular economy", has received special attention among leading scientists. Proponents of this concept believe that circular growth will help to overcome the climate crisis and will contribute to the development of an inclusive green economy. The very definition of this kind of economy was formulated in their 2019 study by experts from the University of Oxford (Haney et al. 2019), based on a series of interviews conducted with participants in the Platform for Accelerating the Circular Economy (PACE). Most of the interviewed experts agreed that a circular economy is a regenerative type of economy in its design, aimed at preserving the greatest possible value of products, their components and materials, whose growth is not stimulated and does not depend on the exploitation of limited resources. At its core, this type of economy is viewed as a new trajectory for the development of society along the path of sustainability (Fig. 1).

The evolutionary development of the circular economy took place in three main stages (Reike et al. 2018):

Stage I (1970-1990) - waste management - a number of environmental legislative measures were adopted in European countries and the United States. The concept of 3R (reduce, reuse and recycle) is becoming more and more interesting. A principle known as the polluter pays is emerging. The issue of waste management is central, but due to the underdeveloped environmental culture and thinking, there is gaining popularity an approach in which the territory of poorer countries was used for waste disposal and/or recycling;

Stage II (1990-2010) - strategies for environmental efficiency - the idea of environmental payments (payment for pollution). Environmental problems were perceived by society as a 
kind of economic opportunity. In the early 2000s, a number of environmental problems have been recognized as global (ozone depletion, global warming). The scientific community is actively developing possible ways of waste-free production, but applicable only in industry;

Stage III (approximately 2010 - present) - maximum preservation in the era of resource depletion - the concept of a circular economy, having absorbed the ideas of theoretical research to the greatest extent, acquired its final form. The central problem is the posed threat to the mankind survival in connection with the reduction and gradual disappearance of necessary natural resources, the growth of the world's population and the amount of waste. Companies are encouraged to develop taking into account three key principles: green innovation, alternative sources, and a change in the industrial paradigm. At the moment, about 500 companies in the world are using the circular economy strategy.

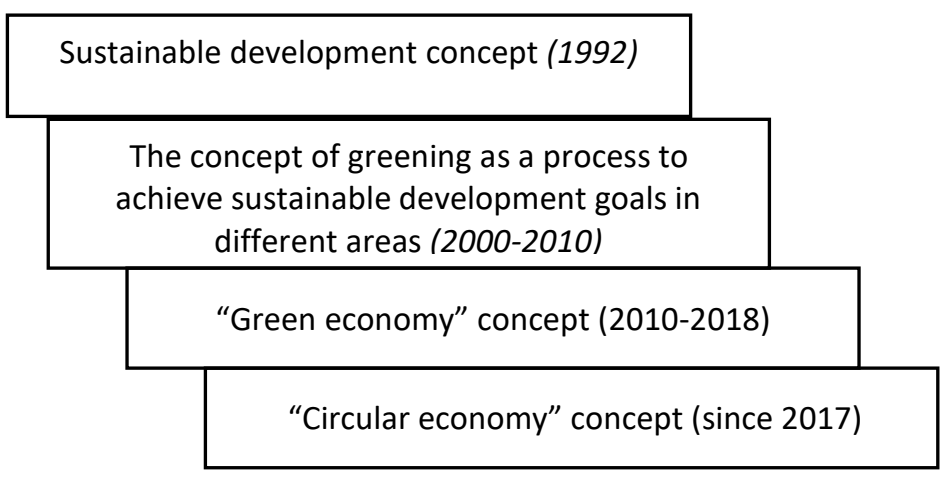

Figure 1. The Ways of Formation and Development of Directions of Economic Development Source: (Gureva 2019).

The transition from industrial to post-industrial society in the 60s. XX century, based on technological progress and an innovative development model, led to the appearance in the scientific literature of the concept of a circular economy. The concept of a circular economy was put forward in 1966 by the American economist Kenneth Ewart Boulding and had a pronounced ecological character: "... a person must find his place in a cyclical ecological system ..." Subsequently, the concept began to acquire a more economic character. (Boulding 1966; Boulding 1966a).

There are various scientific views on the origin of the "circular economy". As a rule, scientists identify it with the concepts of "cyclical economy", "recovery economy", "circular economy", "green economy", etc. A number of scholars believe that the circular economy is a new stage in the development of the concept of sustainable development and a green economy in particular. On the other hand, much less often, it is viewed as an independent direction in economic theory, which originated in the 1970s. XX century (Gureva 2019a; Esipova et al. 2018).

E. Mishenin and I. Koblyanskaya (2017) emphasize that the circular economy is not an analogue of the "green economy", but acts as a component of it, as a way to achieve sustainable development. 
The main interpretations of the concept of "circular economy" offered by different scientific schools are presented in Table 1.

Table 1. Definitions of the Term "Circular Economy"

\begin{tabular}{|c|c|}
\hline Interpretation & $\begin{array}{l}\text { Representatives of the } \\
\text { scientific school }\end{array}$ \\
\hline A policy strategy to reduce resource scarcity and reduce pollution & $\begin{array}{l}\text { Z. Yuan, J. Bi, } \\
\text { Y. Moriguichi (2006) }\end{array}$ \\
\hline A way to solve the problems of sustainable resource development & $\begin{array}{l}\text { C. Wen, Y. Zhao, } \\
\text { R. Liang (2007) }\end{array}$ \\
\hline $\begin{array}{l}\text { Implementation of a closed cycle of material flows in the economic } \\
\text { system }\end{array}$ & $\begin{array}{l}\text { Y. Geng, B. Doberstein } \\
(2008)\end{array}$ \\
\hline A path to sustainable development & H. Zhang et al. (2009) \\
\hline $\begin{array}{l}\text { A way of continuous economic development without creating } \\
\text { significant environmental and resource problems }\end{array}$ & Q. Zhu et al. (2011) \\
\hline $\begin{array}{l}\text { A sustainable development strategy aimed at improving the efficiency } \\
\text { of materials and energy use }\end{array}$ & B. Su et al. (2013) \\
\hline $\begin{array}{l}\text { A holistic concept encompassing the actions of "reduction, } \\
\text { reuse and recycling" in the process of production, circulation and } \\
\text { consumption }\end{array}$ & W. Jiao, F. Boons (2014) \\
\hline $\begin{array}{l}\text { An economic development model with a maximum resource use and } \\
\text { environmental protection }\end{array}$ & F. Wei et al. (2014) \\
\hline $\begin{array}{l}\text { A simple yet compelling strategy that aims at reduction of both the } \\
\text { consumption of raw materials and the volume waste generation by } \\
\text { closing economic and environmental cycles of resource flows }\end{array}$ & et al. (2015) \\
\hline $\begin{array}{l}\text { A mutually beneficial philosophy that prosperous } \\
\text { economy and healthy environment can coexist }\end{array}$ & A. Tukker (2015) \\
\hline $\begin{array}{l}\text { Space to tackle growing resource challenges, a concept to separate the } \\
\text { direct use of resources from economic growth }\end{array}$ & $\begin{array}{l}\text { P. Ghisellini, C. Cialani, } \\
\text { S. Ulgiati (2016) }\end{array}$ \\
\hline $\begin{array}{l}\text { The model of production and consumption of goods through closed } \\
\text { material flows that assimilate external effects associated with the } \\
\text { extraction of primary resources and education waste (including } \\
\text { pollution) }\end{array}$ & $\begin{array}{l}\text { S. Sauve, S. Bernard, } \\
\text { P. Sloan (2016) }\end{array}$ \\
\hline $\begin{array}{l}\text { Addressing a range of issues such as waste generation, resource scarcity } \\
\text { and sustainable economic benefits }\end{array}$ & $\begin{array}{l}\text { M. Lieder, A. Rashid } \\
\text { (2016) }\end{array}$ \\
\hline $\begin{array}{l}\text { Regenerating system, in which resource costs and losses, energy } \\
\text { emissions and leaks are minimized by slowing down, closing and } \\
\text { narrowing material and energy cycles }\end{array}$ & $\begin{array}{l}\text { M. Geissdoerfer et al. } \\
\text { (2017) }\end{array}$ \\
\hline $\begin{array}{l}\text { An economic model in which both the results and the actual resource } \\
\text { supply and production processes are planned and organized in such a } \\
\text { way as to maximize human well-being and the efficiency of ecosystem } \\
\text { functioning }\end{array}$ & $\begin{array}{l}\text { A. Murray, K. Skene, } \\
\text { K. Haynes (2017) }\end{array}$ \\
\hline $\begin{array}{l}\text { An economic system based on business models which replace the } \\
\text { concept of "the end of the product life" with reduction, alternative } \\
\text { reuse, recycling and recovery of materials in production / distribution } \\
\text { and consumption processes, thus functioning at the micro level } \\
\text { (products, companies, consumers), meso level (eco-industrial parks) }\end{array}$ & J. Kirchherr et al. (2018) \\
\hline
\end{tabular}


and macro level (city, region, nation and beyond) with the aim of achieving sustainable development which implies the creation of environmental quality, economic prosperity and social justice in the interests of generations

A sustainable development initiative which aims at reduction of linear material and production flows in the production and consumption systems of the society by applying material cycles, renewable and cascading energy flows to a linear system

An economic model based on the principles of circular functioning of closed technological and biological cycles

A kind of green economy tool for targeted activities to achieve M. Gureva (2019) sustainable development and implementation of key sustainable development goals
A complex multi-level system, whose principles of organization differ significantly from the traditional linear economy
N. Batova,
E. Shershunovich,
I. Tochickaja (2019)

Source: compiled by the authors.

M. Gureva (2019) proposes to group the approaches to interpreting the concept of "circular economy" over the period of its formation as follows: a global economic model (2004); an activity (2007); a new trend 4.0 (2013); an economic model (2015); a production system (2016); an economic activity, tool (2017); philosophy, economics (2018).

Based on the foregoing, the existing scientific approaches to defining the term "circular economy" can be conventionally systematized into groups (Fig. 2).

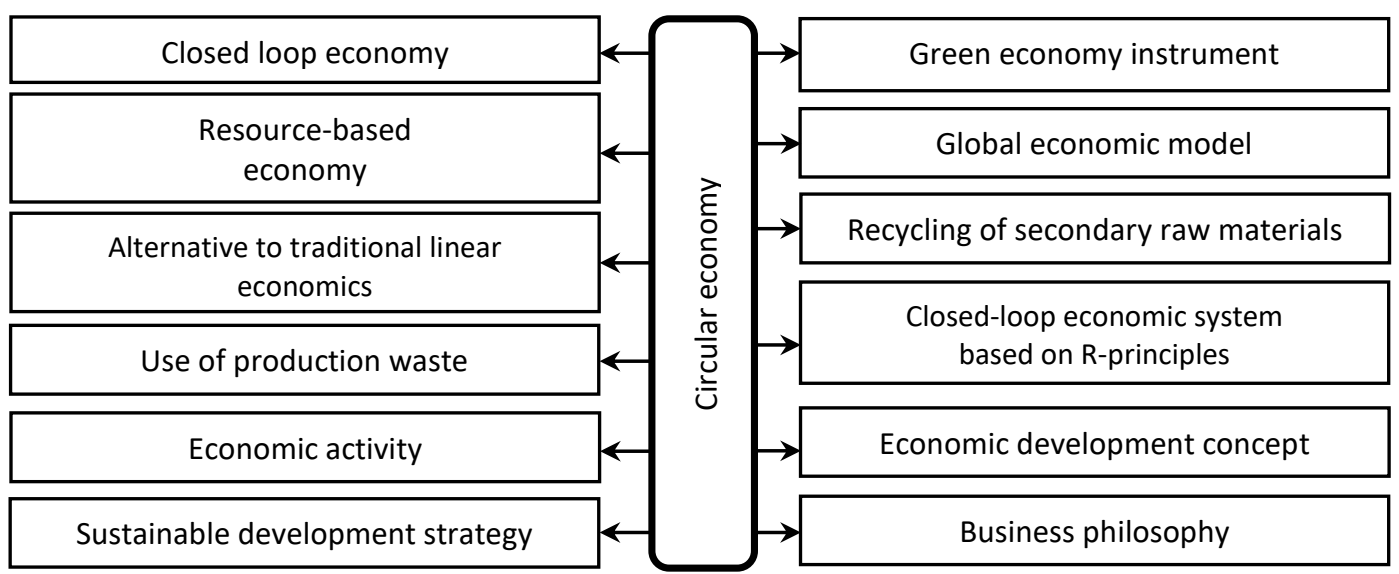

Figure 2. Systematization of the Approaches to the Category "Circular Economy" Offred by Different Scientific Schools

Source: developed by the authors.

Thus, a circular economy should be understood as an innovative approach to organizing logistics processes based on the closed movement of resources with their minimum losses in 
the form of waste and the maximum involvement of secondary resources in production in order to achieve sustainable development of logistics systems.

The literature analysis has shown that the overwhelming number of researchers (Su et al., 2013; Reike \& Vermeulen, Witjes 2018; Kirchherr et al. 2018) uses the prefix "re-", which characterizes the basic essence of the circular economy. The circular economy was originally based on three key principles called "3R": Reduce - Reuse - Recycle. But over time, they transformed into "9R": Rethink - Reduce - Reuse - Repair - Refurbish - Remanufacture Repurpose - Recycle - Recover.

A significant number of studies has been devoted to identifying factors that impede the development of a circular economy (Kirchherr et al. 2017; Pheifer 2017; Ritzén \& Sandströ 2017).

According to scientists (Kirchherr et al., 2018), implementation of the circular economy concept in practice can be hampered by the following barriers:

- cultural (ecological culture of companies, lack of interest and consumer awareness, work according to the principles of a linear economy, interest in the final value chain);

- regulatory (limited closed procurement, lack of global consensus, prohibition of laws and regulations);

- market-based (low quality materials, standardization, high investment value, limited funding for circular business models);

- technological (ability to supply high quality remanufactured products, lack of scale for design demonstrations, lack of required exposure data).

N. Batova et al. (2019) have identified and systematized 5 groups of barriers to the development of a circular economy: socio-cultural, legal, information, technological and economic. Socio-cultural barriers hinder the development of a circular economy due to the existing differences in value attitudes and the level of environmental responsibility of the society. Legal barriers are manifested in the form of restrictions imposed by current legislation. An insufficient consumers' and producers' awareness of the essence and principles and best practices in the circular economy implementation creates information barriers. Economic barriers stem from a variety of factors, including the cost of circular innovation; lack of a clear methodology for assessing the economic efficiency of enterprises using secondary resources, effective mechanisms for financial support and preferences from the banking system, the public sector, and the state are also holding back the introduction of circular processes. It is also economy of scale that makes waste collection and recycling less costeffective for those who generate less waste.

Technological barriers to introducing a circular economy are characterized by the lack of a clear logistics infrastructure for collecting, extracting and processing secondary resources; the lack of demonstration projects for working with new technologies, and as a result, concerns about the quality of products made from recycled materials and waste (Batova et al. 2019). 
As the analysis shows, from the macroeconomic point of view, a circular economic investment strategy could lead by 2030 to a $10 \%$ decrease in the cost of raw materials and a $7 \%$ increase in GDP in the European Union compared to the usual business model (Ellen Mac Arthur Foundation 2017). However, such a leap in development undoubtedly requires a development strategy focused on the specific potential of the economy, as well as appropriate infrastructure and administrative capacities (Müller \& Wilts 2019).

In addition, it should be noted that the development of a circular economy contributes to obtaining a social effect through the creation of jobs. According to a study by the European Commission (2018), depending on how waste is handled, a different number of jobs can be created: for 10 thousand tons of used products, one job can be created during incineration, six jobs - at disposal, 36 jobs - for recycling waste and up to 296 jobs for their recovery and reuse.

Reducing direct and indirect environmental costs is an important long-term opportunity for a circular economy. Direct costs are associated with waste management. However, the indirect costs of using natural resources, which are passed on to the general public, are also relevant. Globally, an international group of resource experts under the United Nations Environment Program estimates that these costs amount to up to 2.4 trillion US dollars (Müller \& Wilts 2019).

Studies by the European Environment Agency (2019) showed that the number of financial resources mobilized by the public sector in the period of 2013-2017 reached the total of 2 billion euros in various areas of the circular economy (Table 2). In the coming years, this volume should increase significantly. For example, during the same period, investments in climate protection reached almost 20 billion euros.

Table 2. Financial Support for the Circular Economy in Different Sectors in the EU

\begin{tabular}{lcc}
\hline \multicolumn{1}{c}{ Sector } & $\begin{array}{c}\text { Amount, } \\
\text { million euros }\end{array}$ & Share, \% \\
\hline Industry and services & 706 & 33 \\
\hline Water resources management & 554 & 26 \\
\hline Agriculture and bioeconomy & 366 & 17 \\
\hline Waste management & 331 & 16 \\
\hline Mobility & 95 & 5 \\
\hline Urban development & 50 & 2 \\
\hline Energy & 14 & 1 \\
\hline Total & 2116 & 100 \\
\hline
\end{tabular}

Source: Based on research by the European Environment Agency (2019).

For example, Finland has the experience in the effective implementation of circular economy solutions. The essence of the transition is to rethink value chains and build on new business models. Currently, there are several solutions developed by specialists from the Finnish 
Innovation Fund Sitra that help to accelerate the transition to a circular economy (Herlevi 2020). These include:

- product-service systems and sharing models;

- ways of value attitudes towards nutrition;

- sustainable delivery models (efficient delivery models and logistics operations are critical for implementing circular economy solutions. RePack offers reusable packaging solutions that minimize the cost of air transport. Koepala offers foldable lunch boxes that are flat for storage and transport and that can be assembled into packaging products of various shapes, which turned the potential of the circular economy into real market results);

- roadmaps for carbon-neutral industries (important for the development of Finland's industry in the future; for example, a 300-million-euro investment in a battery cluster, as well as the first multifunctional textile recycling centre in Northern Europe, will treat $10 \%$ of textile waste; due to resource efficiency and recycling Betolar creates value by converting construction waste into concrete-like building materials with a carbon footprint of up to $90 \%$ less than conventional concrete);

- circular economy education.

Within the framework of the project "Building capacity for strategic planning and management of regional structural transformations in Belarus in the context of a circular economy", the BEROC Centre for Economic Research conducted a survey of 452 enterprises from the Brest and Mogilev regions. The purpose of the survey was to identify the readiness of business for circular transformation (Batova 2020).

As a result of the expert survey, it was found that the circular economy is important in terms of introducing innovations that will allow manufacturing new products and expanding sales markets. At the same time, for a significant number of respondents, the concept of a circular economy is limited only to processing secondary raw materials and using production waste. That is, Belarusian enterprises do not understand that this concept is much broader. For example, they are not familiar with the green procurement tool, which involves taking environmental considerations into account when conducting tenders.

About $30 \%$ of respondents fear that the introduction of the circular economy principles will lead to increased costs and higher prices of the final product. Often a business does not understand that it is not necessary to immediately spend money on implementing a new model; it is enough to implement process innovations within small chains.

Among the main barriers to implementing a closed-loop business model, over $80 \%$ of respondents indicated insufficient financial resources. The second place is taken by the lack of technologies suitable for enterprises, as well as the lack of information and case studies on implementing circular economy approaches. At the same time, about $40 \%$ of respondents indicated that the lack of a unified electronic database on the availability of waste and secondary material resources impedes a large-scale transition to a circular economy. It is in 
the field of waste management where most of the respondents see the main potential for transferring the enterprise's economy to a closed cycle.

In general, when developing long-term development strategies, $80 \%$ of enterprises focus primarily on increasing profits. They consider the introduction of the circular economy principles from the point of view of increasing economic efficiency.

The survey identified the prospects for implementing the principles of a circular economy in Belarus (Batova 2020). The first direction is eco-design. This means that the product is initially designed to minimize environmental damage throughout its entire life cycle. The second is resource efficiency. It implies the organization of cleaner production and the maximum economy of materials, resources, and raw materials. One of the results of implementation is a reduction in financial costs and an increase in competitiveness. The third is the implementation of a circular business model, which consists of many elements, including green supply, the use of environmental innovation, and extension of the product life cycle. The sharing economy, which involves sharing assets and goods, is also a circular business model. This trend is the most developed in the world and gives the maximum growth rates. And another circular business model means product as a service. This approach assumes that, for example, it is not a car that is bought, but the number of kilometres that needs to be travelled, and the manufacturer deals with the service, technical support and disposal.

The fourth priority is industrial symbiosis, which allows businesses to reduce costs through increased collaboration. For example, a by-product of one of them can be a raw material for another. This allows competing by reducing the cost of raw materials.

According to H. Wiltz (2020), Head of the Circular Economy at the Wuppertal Institute for Climate, Environment and Energy, households in Belarus will save the most on transport (up to $80 \%$ ), food (up to $40 \%$ ) and construction due to introducing the circular economy principles (about 25\%).

The concept of green logistics began to take shape in the world since the mid-80s of the 20th century with the emergence of the concept "social responsibility of business". It was revealed that the process of shaping and developing the concept of green logistics was not easy. Thus, foreign scientists J.-P. Rodrigue, B. Slack, and C. Comtois (2001) define the content of the category "green logistics" broadly enough, without the subject and object of research. Within the framework of this concept, a logistics activity is reduced only to a transport distribution system, which must be carried out on environmental principles. In addition, they argue that there are some inconsistencies between the concepts of "green" and "logistics", as cost-saving strategies often conflict with environmental principles, which usually do not take into account environmental costs.

Researchers (Baumgarten 2004; Kümmetsteiner 2011; Christof \& Ehrhart 2012) have shown that the origin, formation and further structuring of "green logistics" are closely intertwined with logistic principles. It has been established that a number of scientists have suggested 
calling the ecological direction of logistics "ecologically oriented logistics," "ecology" or "ecological logistics," which indicates the ecological orientation of logistics activities, as well as the creation of an integrated ecological system.

The analysis of literary sources indicates that over the past decades of developing this scientific direction, scholars have not come to a common and unambiguous interpretation of the term "green logistics". Currently, there are many conceptual approaches to considering the environmental component of logistics. This is due to a significant number of the established scientific schools, which have their own characteristics and approaches to the theoretical and applied aspects of developing the concept of green logistics. However, all the proposed formulations of the terms "green logistics" and "environmental logistics" are usually generally accepted and have a broader meaning, without taking into account the specifics of the functioning of various spheres of economic activity, including transport and logistics.

Thus, this problem determined the purpose of the article, which is to substantiate and develop an organizational and economic mechanism for implementing the concept of green logistics in the context of sustainable development of logistics systems and a circular economy.

\section{Methods}

The methodology of this research is based on the scientific works by foreign and Ukrainian scholars studying green economy, circular economy, logistics, management, marketing, information technology.

The study was carried out using general scientific methods: analysis and synthesis - to generalize the existing theoretical approaches and provisions, scientific developments on the development of a circular economy, green logistics and the greening of logistics systems, clarification of the terminological apparatus; classification - to systematize scientific approaches to defining the concept "circular economy": analysis and generalization of theoretical approaches to the definition of the concept "green logistics" proposed by different scientific schools; a statistical analysis and comparison - to analyse the results of expert surveys of the need for a "green" transformation of logistics systems in the world; statistical analysis of the development of logistics systems, taking into account the environmental component in foreign countries and Ukraine; structural and logical generalization - to identify barriers hindering the development of logistics systems in terms of greening; clarification of wording the term "green logistics"; a systematic approach - to build a structural diagram of forming an organizational and economic mechanism for implementing the concept of green logistics.

Statistics for Ukraine include: GDP at constant 2010 prices; total expenditures (capital investments and operating expenses) for environmental protection, including in the field of transport and storage; budget expenditures for environmental protection; general expenses for the protection of atmospheric air and climate, including in the field of transport and storage; investments in equipment and installations related to integrated environmentally 
friendly technologies; the volume of pollutants' emissions into the air from mobile sources of pollution; the volume of emissions of carbon dioxide into the air from road transport.

These data are taken in the sections "Environment," "Transport," "Activities of enterprises" on the website of the State Statistics Service of Ukraine, as well as in the statistical collections "The Environment of Ukraine 2019," "Activity of business entities 2019".

The amounts of financial support for developing a circular economy in different sectors in the EU are obtained from the website of the European Environment Agency (2019); indicators of the development of the green technology market in the world - on the website of the Bundesministerium für Umwelt, Naturschutz und nukleare Sicherheit (BMU).

It was established that in 2009 the countries of the Organization for Economic Cooperation and Development (OECD) adopted the Strategy for Environmentally Oriented ("Green") Growth as a tool for overcoming the financial and economic crisis for the medium (until 2030) and long-term (until 2050) prospects. South Korea has emerged as the green economy leader, announcing green growth as its national strategy. Following South Korea, China has taken a green economy course. And then, the countries of the European Union began the transition to green development.

According to experts, the expected growth of the global market for green technologies is $6.9 \%$ (this is almost 2 times more than the growth rate of the world economy). According to forecasts, the total volume of this market by 2025 may increase to 5.9 trillion euros (Table 3). If we analyse the data on the structure of the green technologies market, it can be noted that its two main segments are environmentally friendly production, accumulation and distribution of energy ( $21 \%$ and $20 \%$ in 2016 and 2020 ) and the energy efficiency submarket (26\% and $25 \%$ in 2016 and 2020). Sustainable mobility and efficient use are projected to grow by 2025 raw materials and materials (Table 4).

Table 3. Prospects for the Development of the Green Technologies Market in the World in 2016-2025

\begin{tabular}{|c|c|c|c|c|}
\hline \multirow[t]{2}{*}{ Segments } & \multicolumn{2}{|c|}{$\begin{array}{l}\text { Annual value, } \\
\text { billion euros }\end{array}$} & \multirow{2}{*}{$\begin{array}{c}2025 \text { to } 2016 \\
\text { times }\end{array}$} & \multirow{2}{*}{$\begin{array}{l}\text { Average annual } \\
\text { growth rate } \\
\text { in 2016-2025, \% }\end{array}$} \\
\hline & 2016 & 2025 & & \\
\hline $\begin{array}{l}\text { Environmentally friendly production, } \\
\text { accumulation and distribution of } \\
\text { energy (renewable energy sources } \\
\text { (RES), storage, Smart grid }\end{array}$ & 667 & 1164 & 1.75 & 6.4 \\
\hline Energy efficiency submarket & 837 & 1491 & 1.8 & 6.6 \\
\hline $\begin{array}{l}\text { Efficient use of raw materials and } \\
\text { supplies (including the production of } \\
\text { biological substitutes for fossil raw } \\
\text { materials) }\end{array}$ & 521 & 1048 & 2.0 & 8.1 \\
\hline
\end{tabular}




\begin{tabular}{|c|c|c|c|c|}
\hline $\begin{array}{l}\text { Environmentally sustainable mobility } \\
\text { (development of new transport } \\
\text { technologies and biofuel production) }\end{array}$ & 412 & 988 & 2.4 & 10.2 \\
\hline Circular economy & 110 & 210 & 1.9 & 7.4 \\
\hline $\begin{array}{l}\text { Environmentally sustainable water } \\
\text { management (including various } \\
\text { aspects of wastewater management) }\end{array}$ & 667 & 1001 & 1.5 & 4.6 \\
\hline Total & 3214 & 5902 & 1.8 & 6.9 \\
\hline
\end{tabular}

Table 4. The Market Structure of Green Technologies in the World

\begin{tabular}{lcc}
\hline \multicolumn{1}{c}{ Segments } & \multicolumn{2}{c}{ Share, \% } \\
\cline { 2 - 3 } & 2016 & 2025 \\
\hline Energy efficiency submarket & 26 & 25 \\
\hline Environmentally friendly production, accumulation and distribution of energy & 21 & 20 \\
\hline Efficient use of raw materials and supplies & 16 & 18 \\
\hline Environmentally sustainable mobility & 13 & 17 \\
\hline Environmentally sustainable water management & 21 & 17 \\
\hline Circular economy & 3 & 3 \\
\hline
\end{tabular}

Source: BMU (2018).

If we consider the national logistics system of Ukraine in a circular economy, it should be noted that its transformation is not being carried out efficiently enough. According to the Ministry of Finance of Ukraine, the share of budget expenditures on environmental protection (EPP) is insignificant and in 2019 amounted to only $0.7 \%$ of the total volume of state budget expenditures. This, in turn, is not in line with the Sustainable Development Goals 2016-2030. The share of total expenditures on environmental protection in the total GDP is insignificant and amounted to $4.2 \%$ in 2019 (Table 5).

Table 5. Financial and Economic Indicators of the Development of the Sphere of Environmental Protection in Ukraine

\begin{tabular}{lccccc}
\hline Years & $\begin{array}{c}\text { GDP at constant } \\
\text { 2010 prices, UAH } \\
\text { million }\end{array}$ & UAH million & $\begin{array}{c}\text { Share in } \\
\text { GDP, } \%\end{array}$ & $\begin{array}{c}\text { TAH } \\
\text { million }\end{array}$ & $\begin{array}{c}\text { Shal expenditures on EP } \\
\text { volume of budget } \\
\text { expenditures, \% }\end{array}$ \\
\cline { 3 - 6 } 2010 & 1079346.0 & 13128.1 & 1.2 & 2872.4 & 0.8 \\
\hline 2011 & 1138338.0 & 18490.4 & 1.6 & 3890.7 & 0.9 \\
\hline 2012 & 1141055.0 & 20514.0 & 1.8 & 5297.9 & 1.1 \\
\hline 2013 & 1140750.0 & 20377.9 & 1.8 & 5594.2 & 1.1 \\
\hline 2014 & 1066001.0 & 21925.6 & 2.1 & 3481.7 & 0.7 \\
\hline 2015 & 961821.0 & 24591.1 & 2.6 & 5529.7 & 0.8 \\
\hline 2016 & 985299.0 & 32488.7 & 3.3 & 6255.4 & 0.7 \\
\hline 2017 & 1010173.0 & 31492.0 & 3.1 & 7349.3 & 0.7 \\
\hline 2018 & 1043272.0 & 34392.3 & 3.3 & 8242.1 & 0.7 \\
\hline 2019 & 1037299.1 & 43735.9 & 4.2 & 9731.1 & 0.7 \\
\hline
\end{tabular}

Source: (State Statistics Service of Ukraine 2020, pp. 195, 198). 
In 2012-2019, the share of total expenditures on environmental protection (EP) in the field of transport and warehousing decreased by 4.3 percentage points, or from 6.2 to $1.9 \%$ of the total Siterlet expenditures on EP. During this period, there was a trend towards a reduction in the share of capital investments in the development of the transport and storage sector by 51 percentage points, or from 58.8 to $7.8 \%$ of the total Siterlet expenditures on environmental protection in this area. The share of current expenditures on EP in the field of transport and warehousing, respectively, increased by 51 percentage points, or from 41.2 to $92.2 \%$ of the total Siterlet expenditures on environmental protection in this type of economic activity (Table 6).

Table 6. Total Environmental Expenditure in the Field of Transport and Warehousing

\begin{tabular}{|c|c|c|c|c|c|c|c|}
\hline \multirow{3}{*}{ Years } & \multirow{3}{*}{$\begin{array}{c}\text { Total } \\
\text { volume, UAH } \\
\text { million }\end{array}$} & \multirow{2}{*}{\multicolumn{2}{|c|}{$\begin{array}{c}\text { Including } \\
\text { in the field of transport } \\
\text { and warehousing }\end{array}$}} & \multicolumn{4}{|c|}{ Including } \\
\hline & & & & \multicolumn{2}{|c|}{ capital investment } & \multicolumn{2}{|c|}{ operating costs } \\
\hline & & $\begin{array}{c}\text { UAH } \\
\text { million }\end{array}$ & Share, \% & $\begin{array}{c}\text { UAH } \\
\text { million }\end{array}$ & Share, \% & $\begin{array}{c}\text { UAH } \\
\text { million }\end{array}$ & Share, \% \\
\hline 2012 & 20514.0 & 1262.6 & 6.2 & 742.1 & 58.8 & 520.5 & 41.2 \\
\hline 2013 & 20377.9 & 691.6 & 3.4 & 197.6 & 28.6 & 494.0 & 71.4 \\
\hline 2014 & 21925.6 & 330.0 & 1.5 & 78.0 & 23.6 & 252.0 & 76.4 \\
\hline 2015 & 24591.1 & 303.8 & 1.2 & 59.0 & 19.4 & 244.8 & 80.6 \\
\hline 2016 & 32488.7 & 824.9 & 2.5 & 96.7 & 11.7 & 728.2 & 88.3 \\
\hline 2017 & 31492.0 & 575.4 & 1.8 & 65.3 & 11.3 & 510.1 & 88.7 \\
\hline 2018 & 34392.3 & 742.3 & 2.2 & 168.2 & 22.7 & 574.1 & 77.3 \\
\hline 2019 & 43735.9 & 819.0 & 1.9 & 64.0 & 7.8 & 755.0 & 92.2 \\
\hline
\end{tabular}

Source: (State Statistics Service of Ukraine 2020, pp. 191, 194, 198).

In 2012-2019, the share of current costs for OOPS in the field of transport and warehousing decreased by 1.2 percentage points, or from 3.7 to $2.7 \%$ of the total current expenditure on environmental protection. The share of expenses for the protection of atmospheric air and climate in the field of transport and storage facilities decreased by 1.6 percentage points, or from 2.4 to $0.8 \%$ of the total volume of these expenses for all types of economic activity. At the same time, the share of expenses for the protection of atmospheric air and climate in the field of transport and warehousing decreased by 3.1\% in the total current expenditures for environmental protection in this area, or from 6.1 to $3 \%$ (Table 7).

Table 7. Current Expenditures for Environmental Protection

\begin{tabular}{|c|c|c|c|c|c|c|}
\hline \multirow[t]{2}{*}{ Years } & \multirow{2}{*}{$\begin{array}{l}\text { Total volume, } \\
\text { UAH million }\end{array}$} & \multicolumn{2}{|c|}{$\begin{array}{l}\text { including in the field } \\
\text { of transport and } \\
\text { warehousing }\end{array}$} & \multirow{2}{*}{$\begin{array}{l}\text { Of these the costs } \\
\text { of protecting the } \\
\text { atmospheric air and } \\
\text { climate, UAH million }\end{array}$} & \multicolumn{2}{|c|}{$\begin{array}{l}\text { including in the field } \\
\text { of transport and } \\
\text { warehousing }\end{array}$} \\
\hline & & $\begin{array}{l}\mathrm{UAH} \\
\text { million }\end{array}$ & Share, \% & & $\begin{array}{l}\mathrm{UAH} \\
\text { million }\end{array}$ & Share, \% \\
\hline 2012 & 13924.7 & 520.5 & 3.7 & 1330.8 & 31.9 & 2.4 \\
\hline 2013 & 14339.1 & 494.0 & 3.4 & 1411.1 & 29.0 & 2.1 \\
\hline 2014 & 13965.7 & 252.0 & 1.8 & 1234.6 & 22.6 & 1.8 \\
\hline 2015 & 16915.5 & 244.8 & 1.4 & 1512.6 & 60.3 & 4.0 \\
\hline
\end{tabular}




\begin{tabular}{lllllll}
\hline 2016 & 19095.2 & 728.2 & 3.8 & 1755.4 & 32.4 & 1.8 \\
\hline 2017 & 20466.4 & 510.1 & 2.5 & 2086.9 & 31.8 & 1.5 \\
\hline 2018 & 24318.0 & 574.1 & 2.4 & 2897.7 & 26.7 & 0.9 \\
\hline 2019 & 27480.2 & 755.0 & 2.7 & 2963.9 & 22.4 & 0.8 \\
\hline
\end{tabular}

Source: (State Statistics Service of Ukraine 2020, pp. 172, 192, 198).

For the period of 2012-2019, the share of capital investments in environmental protection in the field of transport and warehousing decreased by 10.9 percentage points, or from 11.3 to $0.4 \%$ of the total volume of capital investments in environmental protection for all types of economic activity (Table 8).

Table 8. Capital Investment for Environmental Protection

\begin{tabular}{cccc}
\hline Years & $\begin{array}{c}\text { Total volume, } \\
\text { UAH million }\end{array}$ & $\begin{array}{c}\text { including in the field of transport } \\
\text { and warehousing, UAH million }\end{array}$ & $\begin{array}{c}\text { Share in the total volume } \\
\text { of capital investments, } \%\end{array}$ \\
\hline 2012 & 6589.3 & 742.1 & 11.3 \\
\hline 2013 & 6038.8 & 197.6 & 3.3 \\
\hline 2014 & 7959.9 & 78.0 & 1.0 \\
\hline 2015 & 7675.6 & 59.0 & 0.8 \\
\hline 2016 & 13390.5 & 96.7 & 0.7 \\
\hline 2017 & 11025.6 & 65.3 & 0.6 \\
\hline 2018 & 10074.3 & 168.2 & 1.7 \\
\hline 2019 & 16255.7 & 64.0 & 0.4 \\
\hline
\end{tabular}

Source: (State Statistics Service of Ukraine 2020, pp. 189, 191).

During the study period, the share of investments in equipment and installations related to environmentally friendly technologies in the field of transport and warehousing decreased by 18.2 percentage points, or 21.7 to $3.5 \%$ of the total volume of these investments. The share of investments in integrated technologies for the protection of atmospheric air and climate in the field of transport and storage facilities decreased by 22.8 percentage points, or 44.2 to $21.4 \%$ of the total volume of relevant investments. At the same time, the share of investments in integrated technologies for the protection of atmospheric air and climate in the field of transport and warehousing increased by 29.5 percentage points, or 60.9 to $90.4 \%$ of the total investment in equipment related to environmentally friendly technologies in this industry (Table 9).

Table 9. Investments in Equipment and Installations Related to Integrated Environmentally Friendly Technologies

\begin{tabular}{|c|c|c|c|c|c|c|}
\hline \multirow[t]{2}{*}{ Years } & \multirow{2}{*}{$\begin{array}{l}\text { Total } \\
\text { volume, } \\
\text { UAH million }\end{array}$} & \multicolumn{2}{|c|}{$\begin{array}{l}\text { including in the field } \\
\text { of transport and } \\
\text { warehousing }\end{array}$} & \multirow{2}{*}{$\begin{array}{l}\text { Of these investments for } \\
\text { the protection of } \\
\text { atmospheric air and } \\
\text { climate, UAH million }\end{array}$} & \multicolumn{2}{|c|}{$\begin{array}{c}\text { including in the field } \\
\text { of transport and } \\
\text { warehousing }\end{array}$} \\
\hline & & $\begin{array}{l}\text { UAH } \\
\text { million }\end{array}$ & Share, \% & & $\begin{array}{l}\text { UAH } \\
\text { million }\end{array}$ & Share, \% \\
\hline 2012 & 3714.8 & 806.6 & 21.7 & 1112.2 & 491.5 & 44.2 \\
\hline 2013 & 3233.9 & 191.7 & 5.9 & 1094.2 & 142.7 & 13.0 \\
\hline 2014 & 4638.2 & 70.8 & 1.5 & 428.5 & 11.0 & 2.6 \\
\hline
\end{tabular}




\begin{tabular}{ccccccc}
\hline 2015 & 4952.2 & 49.2 & 1.0 & 436.0 & 10.0 & 2.3 \\
\hline 2016 & 7783.7 & 82.0 & 1.1 & 528.9 & 25.4 & 4.8 \\
\hline 2017 & 4183.4 & 47.5 & 1.1 & 300.1 & 12.0 & 4.0 \\
\hline 2018 & 3519.4 & 125.7 & 3.6 & 514.1 & 114.0 & 22.2 \\
\hline 2019 & 3519.4 & 121.9 & 3.5 & 514.1 & 110.2 & 21.4 \\
\hline
\end{tabular}

Source: (State Statistics Service of Ukraine 2020, p. 134).

For the period of 2010-2019, the volume of pollutants emissions into the air from mobile sources of pollution decreased by $35.2 \%$. And their share in the total volume of pollutants emissions increased by 1.9 percentage points (Table 10).

Table 10. Volumes of Pollutants Emissions into the Air from Mobile Sources of Pollution

\begin{tabular}{cccc}
\hline Years & $\begin{array}{c}\text { Total volume, } \\
\text { thousand tons }\end{array}$ & $\begin{array}{c}\text { including mobile sources } \\
\text { of pollution, thousand tons }\end{array}$ & $\begin{array}{c}\text { Share in the total volume } \\
\text { of pollutant emissions, } \%\end{array}$ \\
\hline 2010 & 6678.0 & 2546.4 & 38.1 \\
\hline 2012 & 6821.1 & 2485.8 & 36.4 \\
\hline 2013 & 6719.8 & 2424.7 & 36.1 \\
\hline 2014 & 5346.2 & 1996.2 & 37.3 \\
\hline 2015 & 4521.3 & 1663.9 & 36.8 \\
\hline 2016 & 4236.0 & 1608.5 & 38.0 \\
\hline 2017 & 3968.7 & 1645.7 & 41.5 \\
\hline 2018 & 4043.9 & 1612.9 & 39.9 \\
\hline 2019 & 4119.0 & 1648.8 & 40.0 \\
\hline
\end{tabular}

Source: (State Statistics Service of Ukraine 2020, pp. 26, 28).

As the analysis shows, the total volume of air emissions from road transport decreased in 2010-2019 by $28.3 \%$, or from 2313.8 to 1659.5 thousand tons. The volume of carbon dioxide emissions into the air from road transport increased by $13.4 \%$, or from 1782.7 to 2021.1 thousand tons (State Statistics Service of Ukraine 2020; Environment of Ukraine 2019, pp. 26, 28).

Thus, the statistical analysis indicates the need to implement the principles and tools of green logistics as a concept for the sustainable development of the national logistics system.

\section{Results}

Based on the analysis of literary sources (Janbo \& Songxian 2008; Brdulak \& Michniewska 2009; Sbihi \& Eglese 2009; Mesjasz-Lech 2011; Ubeda et al. 2011; Lai \& Wong 2012; Dekker et al. 2012; Ćirović et al. 2014; Harris et al. 2014; Jedliński 2014; Seroka-Stolka 2014; Zhang et al. 2015), scientific views on interpreting the essence and content of the concept "green logistics" are generalized. As a rule, scientists understand this term as:

- a scientific direction and one of the factors of environmental preservation, based on resource-saving and environmentally friendly technologies; 
- a new direction, providing for the use of advanced logistics technologies and modern equipment in order to minimize pollution and increase the efficiency of using logistics resources;

- from a theoretical and scientific-methodological point of view, the subordinate functionality of the "green" economy;

- logistics based on resource-saving and environmentally friendly technologies;

- a type of logistics in which scientific and practical activities take into account environmental aspects at all stages of movement of material and other flows corresponding to it in order to reduce destructive effects on the environment and optimize resource consumption;

- an innovative method in logistics;

- within the framework of the concept of sustainable economic development, an effective approach to the management of resource and energy flows to reduce the environmental and economic damage to the environment and ensure effective innovative development of production;

- a system of measures providing for the use of energy and resource-saving logistics technologies and modern equipment in all links of the supply chain in order to minimize the negative impact on the environment and increase the total consumer value of products;

- an environmentally friendly and efficient transport distribution system;

- scientific and practical activities aimed at optimizing and effective management of direct and reverse material and accompanying flows (information, financial, waste flows, harmful emissions, various natural resources and energy) in order to minimize the negative impact on the environment;

- a scientific and practical activity, which provides for the formation of an effective mechanism for integrating environmental and socio-economic aspects at all stages of planning, design and management of the supply chain of goods in order to minimize environmental and economic damage and increase the consumer value of products through the use of energy and resource-saving logistics technologies;

- activities related to the eco-efficient management of the movement of logistics flows of products that move from the enterprise to the consumer, as well as return flows of goods in the "supplier-consumer" system;

- a set of actions related to the assessment and minimization of the environmental consequences of logistics activities;

- a coordination of logistic activities of market entities with a focus on achieving economic and socio-ecological effect through the use of energy and resource saving technologies;

- an increasing environmental responsibility in the transport and logistics sector.

Based on the generalization of the terminological apparatus on the selected topic in accordance with various scientific concepts and as a result of the research (Zaloznova et al. 2018; Trushkina 2018; Koev et al. 2019; Koev et al. 2019a; Sandiuk et al. 2019; Kashchena et al. 2019; Trushkina 2019; Trushkina 2019a; Trushkina et al. 2020; Kwilinski et al. 2020; 
Trushkina 2020; Aleksander et al. 2020; Arefieva et al. 2021;Boiko 2019; Bogachov et al. 2020; Borychowski et al. 2020; Chygryn et al. 2020; Cyfert et al. 2020; 2021; Czakon et al. 2020; Czyżewski et al. 2019; 2020; Dementyev \& Kwilinski 2020; Dementyev et al. 2021; Drozdz et al. 2020; 2021; Dyduch 2019a; 2019b; Dzwigol 2019a; 2019b; 2020a; 2020b; 2020c; 2020d; 2021a; 2021b; 2021c; Dzwigol \& Wolniak 2018; Dzwigol \& Dźwigoł-Barosz 2018; 2020a; 2020b; Dzwigol et al. 2019a; 2019b; 2020a; 2020b; 2021b; Gorynia 2019; Gorynia et al. 2019; Hrytsenko et al. 2021; Kaźmierczyk \& Chinalska 2018; Kharazishvili et al. 2021a; 2021b; Khrapkina et al. 2021; Koibichuk et al. 2021; Kondratenko et al. 2020; Kuzior et al. 2019; 2021a; 2021b; Kwilinski 2018a; 2018b; 2019; 2021; Kwilinski et al. 2019a; 2019b; 2019c; 2019d; 2019e; 2019f; 2020a; 2020b; 2020c; 2020d; 2020e; 2021; Kwilinski \& Kuzior 2020; Kyrylov et al. 2020; Lakhno et al. 2018; Lyulyov et al. 2020a; 2020b; 2021a; 2021b; 2021c; Mlaabdal et al. 2020; Miskiewicz 2017a; 2017b; 2018; 2019; 2020a; 2020b; 2021a; 2021b; Miśkiewicz \& Wolniak 2020; Pająk et al. 2016; 2017; Polcyn 2018; 2021; Prokopenko \& Miskiewicz 2020; Saługa et al. 2020; Savchenko et al. 2019; Tkachenko et al. 2019a; 2019b; 2019c; 2019d; 2019e; Trąpczyński et al. 2019; Zastempowski et al. 2020), the authors' approach to defining the term "green logistics" is offered. It is understood as a circular economy instrument; a component of corporate social responsibility of business in the transport sector and logistics activities; a type of economic activity, including the processes of material and technical supply, warehousing, environmentally friendly storage, production, customer service, transportation, sale of finished products, recycling (recycling and waste disposal), which allows reducing the negative impact on the ecosystem and the environment in a circular economy.

For the effective implementation of the green logistics concept, it is advisable to develop an organizational and economic mechanism, which is considered as a set of principles, tools, functions, methods and means aimed at reducing the level of greenhouse gas emissions and the costs of organizing logistics activities and various logistics services (transport, warehousing, marketing, etc.) (Fig. 3, 4).

The components of the organizational and economic mechanism include resources; factors of influence; goals, principles, functions, methods, control levers; tools; information technology; and performance criteria. The key principles of forming the organizational and economic mechanism comprise consistency, integration, reliability, dynamism, compliance with the goals of sustainable development, and efficiency. 
Diagnostics of the current state, features and trends in the development of logistics systems, taking into account the environmental component

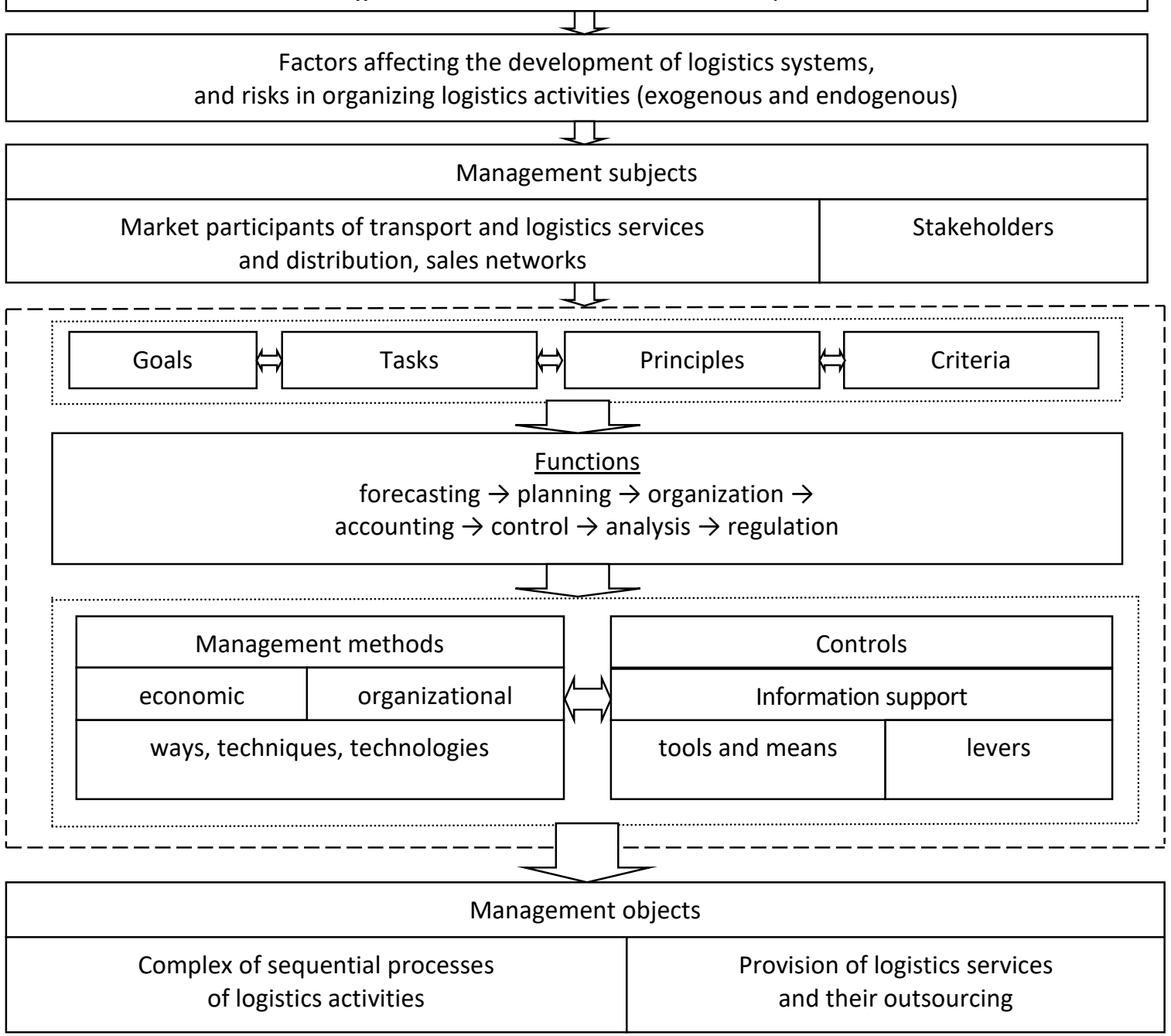

Figure 3. The Main Elements of the Organizational and Economic Mechanism for Implementing the Concept of Green Logistics

Source: developed by the authors. 


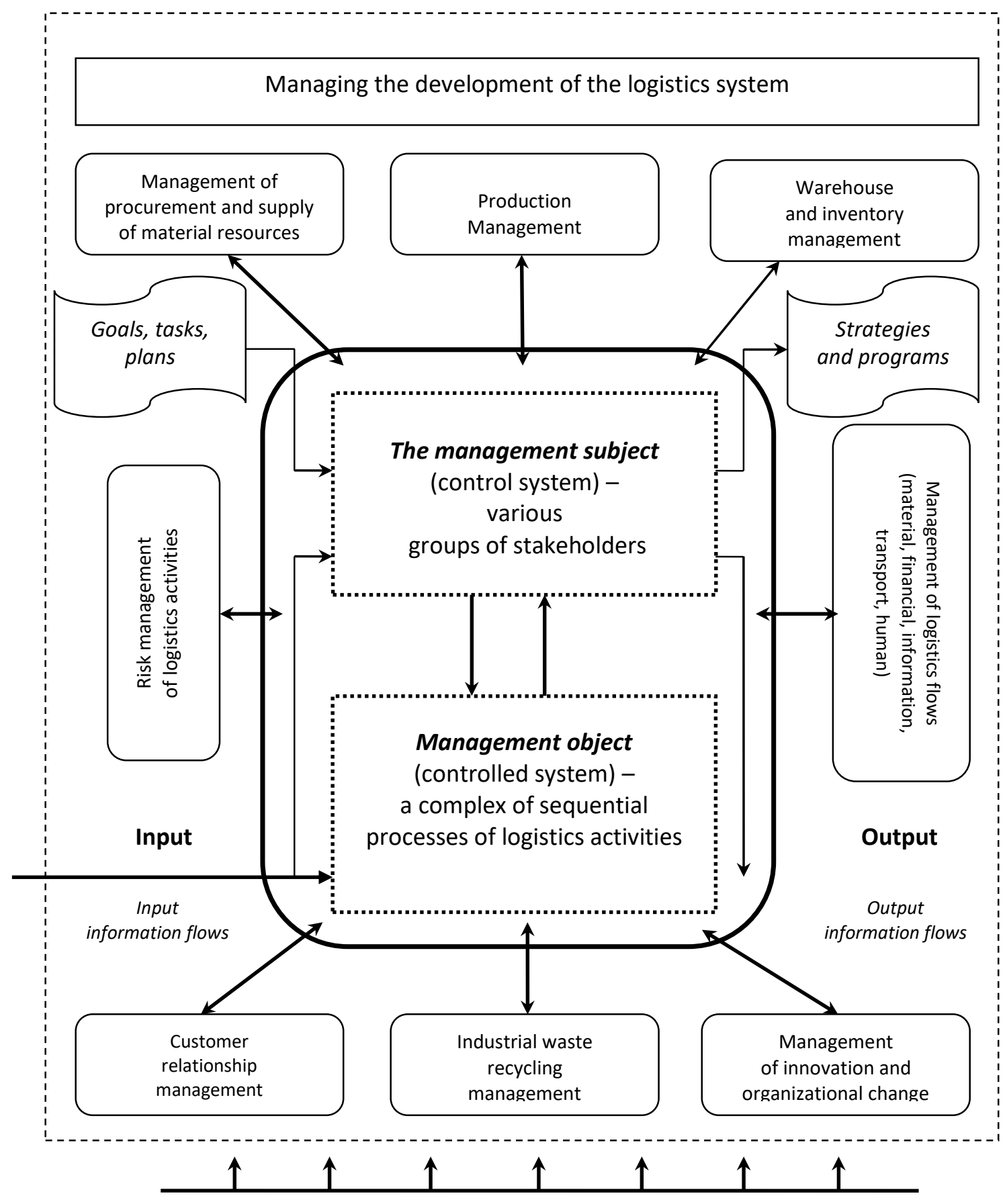

Environmental factors

Figure 4. A Flowchart of Forming an Organizational and Economic Mechanism for Implementing the Concept of Green Logistics

Source: developed by the authors. 


\section{Conclusions}

In modern conditions of intensive development of the circular economy, the issues of environmental protection in the transport sector and in the organization of logistics activities are actualized. This should be done in the context of green growth and in line with the European TEN-T transport policy aimed at using resources efficiently and reducing greenhouse gas emissions.

It has been proven that green logistics is an effective tool for transforming logistics systems. Based on the analysis and generalization of existing scientific approaches to defining the term "green logistics", it was established that the term is understood differently, namely as a factor of preserving the environment with the help of environmentally friendly technologies; a component of the green economy; a type of logistics; an economic activity; scientific and practical activities; a type of activity related to the eco-efficient management of the movement of logistics product flows; a tool for ensuring the ecological safety of the ecosystem; a set of logistic approaches to optimizing waste and resource flows; an environmentally friendly transport distribution system; a coordination of logistics activities to achieve sustainable development.

At the same time, most scientists identify the concepts of "green" and "ecological logistics", which is understood as a scientific direction that involves using modern innovative logistics technologies; a set of actions aimed at minimizing the environmental consequences of logistics activities; integrated management of logistic processes (production, storage, waste transportation); a subsystem for managing product flows from supplier to consumer with minimal impact on the environment.

As a result of the study, it was proposed to consider the term "green logistics" from four scientific viewpoints: as a concept of sustainable development of logistics systems of different levels; a circular economy tool; a component of business corporate social responsibility; a type of walking activity.

The main principles of green logistics should be the application of an integrated approach to managing logistics flows; the rational use of resources (production, financial, energy, information); the minimal use of raw materials and packaging that are not recyclable; economically sound and environmentally friendly transportation and storage of material resources; the maximum use of production waste, containers and packaging as secondary raw materials or their environmentally friendly disposal; optimization of costs for organizing logistics activities; minimization of risks in the operation of transport and logistics systems; increasing the level of environmental education and personnel responsibility; introduction of innovative technologies to reduce the environmental burden on the environment; an application of information systems and digital technologies in the field of environmental protection. 
The implementation of the green logistics mechanism helps to minimize the costs of managing the movement of logistics flows while maintaining the required level of environmental safety, which is one of the important requirements for the implementation of the concept of corporate social responsibility of business in a circular economy.

In further scientific research, it is planned to develop the authors' approach to defining the concepts of "green investment" and "green financing of infrastructure projects"; to conduct a SWOT analysis of the logistics systems' development, taking into account the environmental component on the example of different countries of the world; analyse and summarize international experience of "green" transformation of logistics systems in a circular economy.

\section{References}

Abazov, R. (2021). Education for sustainable development and ICT: The case of MDP program at alFarabi KazNU. Herald of Journalism, 58(4), 34-43. https://doi.org/10.26577/HJ.2020.v58.i4.04

Aleksander, A., Krawczyk, D., Kuzior, A., \& Kwilinski, A. (2020). The Conditions Affecting the Functioning of the Mass Media and Social Media Based on Empirical Research Conducted in Ukraine. In Khalid S. Soliman (Ed.), Proceedings of the 36th International Business Information Management Association (IBIMA) 4-5 November 2020 (pp. 10330-10342). Granada, Spain: IBIMA Publishing.

Arefieva, O., Polous, O., Arefiev, S., Tytykalo, V., \& Kwilinski, A. (2021). Managing sustainable development by human capital reproduction in the system of company's organizational behaviour. IOP Conference Series: Earth and Environmental Science, 628, 012039.

Batova, N., Shershunovich, E., Tochickaja, I. (2019). Circular Economy in Belarus: barriers to transition. BEROC Green Economy Policy Paper Series, PP no. 9. Retrieved from http://www.beroc.by/upload/iblock/41c/41c28e417ff84b7b98895d34ab20c782.pdf (accessed 27 May 2021). [in Russian]

Batova, N., Sachek, P., Tochickaja, I. (2019). Financing circular business projects. BEROC Green Economy Policy Paper Series, PP no. 9. Retrieved from http://www.beroc.by/webroot/delivery/ files/PP_GE_6_finance.pdf (accessed 27 May 2021). [in Russian]

Batova, N. (2020). Circular transformation in Belarus is a small-step strategy. October 14. Retrieved from https://zautra.by/news/ekspert-tcirkuliarnaia-transformatciia-v-belarusi-eto-strategiiamalykh-shagov (accessed 21 May 2021). [in Russian]

Baumgarten, H. (2004). Supply Chain Steuerung und Services. Logistik Dienstleister managen globale Netzwerke. Best Practices. Berlin, Springer, Auflage.

BMU (2018). Schulze: GreenTech ist Modernisierungstreiber unserer Wirtschaft. April 13. Retrieved from https://www.bmu.de/pressemitteilung/schulze-greentech-ist-modernisierungstreiberunserer-wirtschaft/ (accessed 21 May 2021).

Boichuk, N., Kauf, S. (2019). Sustainable logistics: a framework for green city logistics - examples of Polish cities. Conference Proceedings of the 9th Carpathian Logistics Congress - CLC 2019, December 2-4, 2019, Zakopane, Poland, 339-346.

Boiko, V., Kwilinski, A., Misiuk, M., \& Boiko, L. (2019). Competitive Advantages of Wholesale Markets of Agricultural Products as a Type of Entrepreneurial Activity: The Experience of Ukraine and Poland. Economic Annals-XXI, 175(1-2), 68-72. https://doi.org/10.21003/ea.V175-12

Bogachov, S., Kwilinski, A., Miethlich, B., Bartosova, V., \& Gurnak, A. (2020). Artificial Intelligence 
Components and Fuzzy Regulators in Entrepreneurship Development. Entrepreneurship and Sustainability Issues, 8(2), 487-499. http://doi.org/10.9770/jesi.2020.8.2(29)

Borychowski, M., Stępień, S., Polcyn, J., Tošović-Stevanović, A., Ćalović, D., Lalić, G., \& Žuža, M. (2020). Socio-Economic Determinants of Small Family Farms' Resilience in Selected Central and Eastern European Countries. Sustainability, 12(24), 10362. http://doi.org/10.3390/su122410362

Boulding, K. E (1966). Economic Analysis; Volume I Microeconomics (Hardcover). 4th ed. New York: Harper \& Row.

Boulding, K. (1966a). The Economics of the Coming Spaceship Earth. In: Jarrett, H., Ed., Environmental Quality in a Growing Economy, Resources for the Future. Johns Hopkins University Press, Baltimore, 3-14.

Brdulak, H., Michniewska, K. (2009). Zielona logistyka, ekologistyka, zrownowa zony rozwoj w logistyce. Koncepcje i strategie logistyczne. Logistyka, 4, 8-15.

Christof, Dr., Ehrhart, E. (2012). Delivering Tomorrow: Towards Sustainable Logistics. Bonn, Germany: Deutsche Post AG.

Ćirović, G., Pamučar, D., Božanić, D. (2014). Green logistic vehicle routing problem: Routing light delivery vehicles in urban areas using a neuro-fuzzy model. Expert Systems with Applications, 41(9), 4245-4258. https://doi.org/10.1016/j.eswa.2014.01.005

Chygryn, O., Bilan, Y., \& Kwilinski, A. (2020). Stakeholders of Green Competitiveness: Innovative Approaches for Creating Communicative System. Marketing and Management of Innovations, 3, 356-368. https://doi.org/10.21272/mmi.2020.3-26

Cyfert, S., Glabiszewski, W., Krzakiewicz, K., \& Zastempowski, M. (2020). The Importance of Dynamic Capabilities in the Processes of Alignment of Chemical Industry Enterprises to Changes in the Environment. Przemysl Chemiczny, 99(6), 953-956.

Cyfert, S., Chwiłkowska-Kubala, A., Szumowski, W., \& Miśkiewicz, R. (2021). The process of developing dynamic capabilities: The conceptualization attempt and the results of empirical studies. PLoS ONE 16(4): e0249724. https://doi.org/10.1371/journal.pone.0249724

Czakon, W., Kawa, A., \& Scott, S. (2020). Network Orientation of Logistics Service Providers: The Construct, Dimensionality and Measurement Scale. International Journal of Logistics Research and Applications, 23(5), 474-492. https://doi.org/10.1080/13675567.2019.1705260

Czyżewski, B., Matuszczak, A., \& Miskiewicz, R. (2019). Public goods versus the farm price-cost squeeze: shaping the sustainability of the EU's common agricultural policy. Technological and Economic Development of Economy, 25(1), 82-102. https://doi.org/10.3846/tede.2019.7449

Czyżewski, B., Matuszczak, A., Polcyn, J., Smędzik-Ambroży, K., \& Staniszewski, J. (2020). Deadweight loss in environmental policy: The case of the European Union member states. Journal of Cleaner Production, 260, 121064. https://doi.org/10.1016/j.jclepro.2020.121064

Dalevska, N., Khobta, V., Kwilinski, A., \& Kravchenko, S. (2019). A Model for Estimating Social and Economic Indicators of Sustainable Development. Entrepreneurship and Sustainability Issues, 6(4), 1839-1860. https://doi.org/10.9770/jesi.2019.6.4(21)

Dekker, R., Bloemhof, J., Mallidis, I. (2012). Operations Research for Green Logistics - an overview of aspects, issues, contributions and challenges. European Journal of Operational Research, 219(3), 671-679.

Dementyev, V.V., \& Kwilinski, A. (2020). Institutsionalnaya sostavlyayuschaya izderzhek proizvodstva [Institutional Component of Production Costs]. Journal of Institutional Studies, 12(1), 100-116. https://doi.org/10.17835/2076-6297.2020.12.1.100-116 
Dementyev, V., Dalevska, N., \& Kwilinski, A. (2021). Institutional Determinants of Structuring the World Political and Economic Space. In Khalid S. Soliman (Ed.), Proceedings of the 37th International Business Information Management Association (IBIMA), 1-2 April 2021 (pp. 2187-2199). Cordoba, Spain: IBIMA Publishing.

Drozdz, W., Miskiewicz, R., Pokrzywniak, J., \& Elzanowski, F. (2019). Urban Electromobility in the Context of Industry 4.0. Torun: Wydawnictwo Adam Marszalek.

Drozdz, W., Marszalek-Kawa, J., Miskiewicz, R., \& Szczepanska-Waszczyna, K. (2020). Digital Economy in the Comporary World. Torun: Wydawnictwo Adam Marszalek.

Dyduch, W. (2019a). Entrepreneurial Strategy Stimulating Value Creation: Conceptual Findings and Some Empirical Tests. Entrepreneurial Business and Economics Review, 7(3), 65-82. https://doi.org/10.15678/EBER.2019.070304

Dyduch, W. (2019b). Organizational Design Supporting Innovativeness. Przeglqd Organizacji, 6, 16-23. https://doi.org/10.33141/po.2019.06.02

Dzwigol, H. (2019a). The Concept of the System Approach of the Enterprise Restructuring Process. Virtual Economics, 2(4), 46-70. https://doi.org/10.34021/ve.2019.02.04(3)

Dzwigol, H. (2019b). Research Methods and Techniques in New Management Trends: Research Results. Virtual Economics, 2(1), 31-48. https://doi.org/10.34021/ve.2019.02.01(2)

Dzwigol, H. (2020a). Innovation in Marketing Research: Quantitative and Qualitative Analysis. Marketing and Management of Innovations, 1, 128-135. http://doi.org/10.21272/mmi.2020.110

Dźwigoł, H. (2020b). Interim Management as a New Approach to the Company Management. Review of Business and Economics Studies, 8(1), 20-26. https://doi.org/10.26794/2308-944X-2020-8-120-26

Dzwigol, H. (2020c). Methodological and Empirical Platform of Triangulation in Strategic Management. Academy of Strategic Management Journal, 19(4), 1-8.

Dzwigol, H. (2021a). Meta-Analysis in Management and Quality Sciences. Marketing and Management of Innovation, 1, 324-335. https://doi.org/10.21272/mmi.2021.1-25

Dźwigoł, H. (2021b). Contemporary Model of Market Economy under Conditions of Uncertainty. In Khalid S. Soliman (Ed.), Proceedings of the 37th International Business Information Management Association (IBIMA), 1-2 April 2021 (pp. 3769-3778). Cordoba, Spain: IBIMA Publishing.

Dźwigoł, H. (2021c). Leadership in the Research: Determinants of Quality, Standards and Best Practices. Business Ethics and Leadership, 5(1), 45-56. https://doi.org/10.21272/bel.5(1).45-56.2021

Dzwigol, H., \& Wolniak, R. (2018). Controlling w procesie zarządzania chemicznym przedsiębiorstwem produkcyjnym [Controlling in the management process of a chemical industry production company]. Przemys/ Chemiczny, 97(7), 1114-1116. https://doi.org/10.15199/62.2018.7.15

Dzwigol, H., \& Dźwigoł-Barosz, M. (2018). Scientific Research Methodology in Management Sciences. Financial and Credit Activity: Problems of Theory and Practice, 2(25), 424-437. https://doi.org/10.18371/fcaptp.v2i25.136508

Dzwigol, H., \& Dzwigol-Barosz, M. (2020a). Sustainable Development of the Company on the Basis of Expert Assessment of the Investment Strategy. Academy of Strategic Management Journal, 19(5), 1-7.

Dzwigol, H., \& Dzwigol-Barosz, M. (2020b). Determinants of the World Investment Market Development in the Context of Global Transformations. In Khalid S. Soliman (Ed.), Proceedings 
of the 36th International Business Information Management Association (IBIMA) 4-5 November 2020 (pp. 9109-9116). Granada, Spain: IBIMA Publishing.

Dzwigol, H., Shcherbak, S., Semikina, M., Vinichenko, O., \& Vasiuta, V. (2019a). Formation of Strategic Change Management System at an Enterprise. Academy of Strategic Management Journal, 18(SI1), 1-8.

Dzwigol, H., Aleinikova, O., Umanska, Y., Shmygol, N., \& Pushak, Y. (2019b). An Entrepreneurship Model for Assessing the Investment Attractiveness of Regions. Journal of Entrepreneurship Education, 22(1S), 1-7.

Dzwigoł, H., Dzwigoł-Barosz, M., Zhyvko, Z., Miskiewicz, R., \& Pushak, H. (2019c). Evaluation of the Energy Security as a Component of National Security of the Country. Journal of Security and Sustainability Issues, 8(3), 307-317. http://doi.org/10.9770/jssi.2019.8.3(2)

Dzwigol, H., Dźwigoł-Barosz, M., \& Kwilinski, A. (2020a). Formation of Global Competitive Enterprise Environment Based on Industry 4.0 Concept. International Journal of Entrepreneurship, 24(1), 15.

Dzwigol, H., Dzwigol-Barosz, M., Miskiewicz, R., \& Kwilinski, A. (2020b). Manager Competency Assessment Model in the Conditions of Industry 4.0. Entrepreneurship and Sustainability Issues, 7(4), 2630-2644. https://doi.org/10.9770/jesi.2020.7.4(5)

Dźwigoł, H., Kwilinski, A., \& Trushkina, N. (2021b). Green Logistics as a Sustainable Development Concept of Logistics Systems in a Circular Economy. In Khalid S. Soliman (Ed.), Proceedings of the 37th International Business Information Management Association (IBIMA), 1-2 April 2021 (pp. 10862-10874). Cordoba, Spain: IBIMA Publishing.

Ellen MacArthur Foundation (2017). Achieving, Growth Within. A 320-Billion Circular Economy Investment Opportunity available to Europe up to 2025. Brüssel.

Esipova, O. V., Blazhnov, N. M., Satsyuk, I. A. (2018). Tsirkulyarnaya ekonomika [Circular economy]. Modern science: current issues, achievements and innovations, 107-110. [(in Russian].

Europäische Kommission (2018). Impacts of circular economy policies on the labour market. Final Report and Annexes. Luxembourg.

European Environment Agency (2019). Paving the way for a circular economy. Insights on status and potentials. EEA Report No. 11/2019. Publications Office of the European Union. Luxemburg.

Geissdoerfer, M., et al. (2017). The Circular Economy e A new sustainability paradigm? J. Clean. Prod., 143, 757-768. https://doi.org/10.1016/j.jcle-pro.2016.12.048

Geng, Y., Doberstein, B. (2008). Developing the circular economy in China: Challenges and opportunities for achieving'leapfrog development. Int. J. Sustain. Dev. World Ecol., 15, 231-239. https://doi.org/10.3843/SusDev.15.3

Ghisellini, P., Cialani, C., Ulgiati, S. (2016). A review on circular economy: the expected transition to a balanced interplay of environmental and economic systems. J. Clean. Prod., 114. 11-32.

Gorynia, M., Trąpczyński, P., \& Bytniewski, S. (2019). The Concepts of Strategy and Business Models in Firm Internationalization Research: Towards a Research Agenda. International Entrepreneurship Review, 5(2), 7-21. https://doi.org/10.15678/ier.2019.0502.01

Gorynia, M. (2019). Competition and Globalisation in Economic Sciences. Selected Aspects. Economics and Business Review, 5(3), 118-133. https://doi.org/10.18559/ebr.2019.3.7 
Gureva, M. A. (2019). Teoreticheskie osnovy kontsepta tsirkulyarnoy ekonomiki [The theoretical basis of the concept of circular economy]. Journal of International Economic Affairs, 9(3), 2311-2336. https://doi.org/10.18334/eo.9.3.40990. [in Russian]

Gureva, M .A. (2019). Teoreticheskie osnovy tsirkulyarnoy ekonomiki [The theoretical basis of circular economy]. Culture and the environment - the basics of sustainable development of Russia. Green bridge through the generations, 54-59. [in Russian]

Haas, W., Krausmann, F., Wiedenhofer, D., Heinz, M. (2015). How Circular is the Global Economy?: An Assessment of Material Flows, Waste Production, and Recycling in the European Union and the World in 2005. Journal of Industrial Ecology, 5. https://doi.org/ 10.1111/jiec.12244

Haney, A., Krestyaninova, O., Love, Ch. (2019). The Circular Economy Boundaries and Bridges. Oxford: Said Business School, University of Oxford. Retrieved from https://www.sbs.ox.ac.uk/sites/default/files/2019-09/the-circular-economy.pdf (accessed 25 May 2021).

Harris, I., Mumford, C.L., Naim, M.M. (2014). A hybrid multi-objective approach to capacitated facility location with flexible store allocation for green logistics modeling. Transportation Research Part $E$. Logistics and Transportation Review, 66, 1-22. https://doi.org/10.1016/j.tre.2014.01.010

Hrytsenko, L., Boiarko, I., Tverezovska, O., Polcyn, J., \& Miskiewicz, R. (2021). Risk-Management of Public-Private Partnership Innovation Projects. Marketing and Management of Innovations, 2, 155-165. http://doi.org/10.21272/mmi.2021.2-13

Janbo, L., Songxian, L. (2008). The Form of Ecological Logistics and Its Relationship Under the Globalization. Ecological Economy, 4, 290-298.

Jedliński, M. (2014). The Position of Green Logistics in Sustainable Development of a Smart Green City. Procedia - Social and Behavioral Sciences, 151, 102-111. https://doi.org/10.1016/j.sbspro.2014.10.011

Jiao, W., Boons, F. (2014). Toward a research agenda for policy intervention and facilitation to enhance industrial symbiosis based on a comprehensive literature review. Journal of Cleaner Production, 67(15), 14-25. https://doi.org/10.1016/j.jclepro.2013.12.050

Kashchena, N., Solokha, D., Trushkina, N., Potemkin, L., Mirkurbanova, R. (2019). Use of multi-agent simulation modeling for predicting the sales of wholesale trade companies. Journal of Management Information and Decision Sciences, 22(4), 483-488.

Kaźmierczyk, J., \& Chinalska, A. (2018). Flexible forms of employment, an opportunity or a curse for the modern economy? Case study: banks in Poland. Entrepreneurship and Sustainability Issues 6(2), 782-798. https://doi.org/10.9770/jesi.2018.6.2(21)

Kharazishvili, Y., Kwilinski, A., Grishnova, O., \& Dzwigol, H. (2020). Social Safety of Society for Developing Countries to Meet Sustainable Development Standards: Indicators, Level, Strategic Benchmarks (with Calculations Based on the Case Study of Ukraine). Sustainability, 12(21), 8953. https://doi.org/10.3390/su12218953

Kharazishvili, Y., Kwilinski, A., Sukhodolia, O., Dzwigol, H., Bobro, D., \& Kotowicz, J. (2021a). The Systemic Approach for Estimating and Strategizing Energy Security: The Case of Ukraine. Energies, 14(8), 2126. https://doi.org/10.3390/en14082126

Kharazishvili, Y., Kwilinski, A., Dzwigol, H., Liashenko, V., \& Lukaszczyk, L. (2021b). Identification and Comparative Analysis of Ukrainian and Polish Scientific-Educational and Innovative Spaces of European Integration. In Khalid S. Soliman (Ed.), Proceedings of the 37th International Business 
Information Management Association (IBIMA), 1-2 April 2021 (pp. 3707-3721). Cordoba, Spain: IBIMA Publishing.

Khrapkina, V., Kwilinski, A., Polcyn, J., Pająk, K., Stratonov, V., \& Kobets, V. (2021). Creation of a Reserve Fund as a Tool for Ensuring the Financial Security of an Enterprise. In Khalid S. Soliman (Ed.), Proceedings of the 37th International Business Information Management Association (IBIMA), 12 April 2021 (pp. 3610-3627). Cordoba, Spain: IBIMA Publishing.

Kirchherr, J., Hekkert, M. Bour, R., Huibrechtse-Truijens, A., Kostense-Smit, E., Muller, J. (2017). Breaking the Barriers to the Circular Economy. Deloitte.

Kirchherr, J., et al. (2018). Barriers to the circular economy: evidence from the European Union (EU). Ecological Economics, 150, 264-272. https://doi.org/10.1016/j.ecolecon.2018.04.028

Koibichuk, V., Ostrovska, N., Kashiyeva, F., \& Kwilinski, A. (2021). Innovation Technology and Cyber Frauds Risks of Neobanks: Gravity Model Analysis. Marketing and Management of Innovations, 1, 253-265. http://doi.org/10.21272/mmi.2021.1-19

Kondratenko, V., Okopnyk, O., Ziganto, L., \& Kwilinski, A. (2020). Innovation Development of Public Administration: Management and Legislation Features. Marketing and Management of Innovations, 1, 87-94. https://doi.org/10.21272/mmi.2020.1-06

Koev, S.R., Tryfonova, O., Inzhyievska, L., Trushkina, N., Radieva, M. (2019). Management of Domestic Marketing of Service Enterprises. IBIMA Business Review, 2019, Article 681709. https://doi.org/ 10.5171/2019.681709

Koev, S.R., Tryfonova, O., Inzhyievska, L., Trushkina, N., Radieva, M. (2019a). Contact personnel assessment as a prerequisite for introduction of internal marketing system. Proceedings of the 33rd International Business Information Management Association Conference, IBIMA 2019: Education Excellence and Innovation Management through Vision 2020, 6497-6510.

Kojvisto, T. (2020). The Finnish Five: Circular Economy (interview with Kari Herlevi). September 25. Retrieved from https://www.goodnewsfinland.com/ru/feature/finskaya-pyaterka-tsirkulyarnayaekonomika/ (accessed 1 June 2021). [in Russian]

Korhonen, J., et al. (2018). Circular economy as an essentially contested concept. Journal of Cleaner Production, 175, 544-552. https://doi.org/10.1016/j.jclepro.2017.12.111

Kümmetsteiner, G. (2011). Handbuch 'Ökologistik. Hochschule Amberg-Weiden.

Kuzior, A., Kwilinski, A., \& Tkachenko, V. (2019). Sustainable Development of Organizations Based on the Combinatorial Model of Artificial Intelligence. Entrepreneurship and Sustainability, 7(2), 1353-1376. http://doi.org/10.9770/jesi.2019.7.2(39)

Kuzior, A., Kwilinski, A., \& Hroznyi, I. (2021a). The Factorial-Reflexive Approach to Diagnosing the Executors' and Contractors' Attitude to Achieving the Objectives by Energy Supplying Companies. Energies, 14(9), 2572. https://doi.org/10.3390/en14092572

Kuzior, A., Lyulyov, O., Pimonenko, T., Kwilinski, A., \& Krawczyk, D. (2021b). Post-Industrial Tourism as a Driver of Sustainable Development. Sustainability, 13(15), 8145. https://doi.org/10.3390/su13158145

Kwilinski, A. (2018a). Mechanism of Formation of Industrial Enterprise Development Strategy in the Information Economy. Virtual Economics, 1(1), 7-25. https://doi.org/10.34021/ve.2018.01.01(1)

Kwilinski, A. (2018b). Mechanism of Modernization of Industrial Sphere of Industrial Enterprise in Accordance with Requirements of the Information Economy. Marketing and Management of Innovations, 4, 116-128. http://doi.org/10.21272/mmi.2018.4-11 
Kwilinski, A. (2019). Implementation of Blockchain Technology in Accounting Sphere. Academy of Accounting and Financial Studies Journal, 23(SI2), 1-6.

Kwilinski, A. (2021). Reflexive Management. Lublin, Poland: Wydawnictwo Naukowe TYGIEL.

Kwilinski, A., Tkachenko, V., \& Kuzior, A. (2019a). Transparent Cognitive Technologies to Ensure Sustainable Society Development. Journal of Security and Sustainability Issues, 9(2), 561-570 http://doi.org/10.9770/jssi.2019.9.2(15)

Kwilinski, A., Drobyazko, S., \& Derevyanko, B. (2019b). Synergetic and Value Effects in Corporate Mergers and Acquisitions of International Companies. In Khalid S. Soliman (Ed.), Proceedings of the 34th International Business Information Management Association Conference (IBIMA) 13-14 November 2019. Vision 2025: Education Excellence and Management of Innovations through Sustainable Economic Competitive Advantage in 2019 (pp. 9467-9471). Madrid, Spain: IBIMA Publishing.

Kwilinski, A., Dalevska, N., Kravchenko, S., Hroznyi, I., Kovalenko, I. (2019c). Formation of the Entrepreneurship Model of E-Business in the Context of the Introduction of Information and Communication Technologies. Journal of Entrepreneurship Education, 22(SI1), 1528-2651-22-S1337: 1-7.

Kwilinski, A., Ruzhytskyi, I., Patlachuk, V., Patlachuk, O., \& Kaminska, B. (2019d). Environmental Taxes as a Condition of Business Responsibility in the Conditions of Sustainable Development. Journal of Legal, Ethical and Regulatory Issues, 22(SI2) 1544-0044-22-SI-2-354: 1-6.

Kwilinski, A., Volynets, R., Berdnik, I., Holovko, M., \& Berzin, P. (2019e). E-Commerce: Concept and Legal Regulation in Modern Economic Conditions. Journal of Legal, Ethical and Regulatory Issues, 22(SI2), 1544-0044-22-SI-2-357: 1-6.

Kwilinski, A., Pajak, K., Halachenko, O., Vasylchak, S., Pushak, Ya., \& Kuzior, P. (2019f). Marketing Tools for Improving Enterprise Performance in the Context of Social and Economic Security of the State: Innovative Approaches to Assessment. Marketing and Management of Innovations, 4, 172-181. http://doi.org/10.21272/mmi.2019.4-14

Kwilinski, A., \& Kuzior, A. (2020). Cognitive Technologies in the Management and Formation of Directions of the Priority Development of Industrial Enterprises. Management Systems in Production Engineering, 28(2), 119-123. http://doi.org/10.1515/mspe-2019-0020

Kwilinski, A., Vyshnevskyi, O., \& Dzwigol, H. (2020a). Digitalization of the EU Economies and People at Risk of Poverty or Social Exclusion. Journal of Risk and Financial Management, 13(7), 142. https://doi.org/10.3390/jrfm13070142

Kwilinski, A., Zaloznova, Y., Trushkina, N., \& Rynkevych, N. (2020b). Organizational and Methodological Support for Ukrainian Coal Enterprises Marketing Activity Improvement. E3S Web of Conferences, 168, 00031. https://doi.org/10.1051/e3sconf/202016800031

Kwilinski, A., Dielini, M., Mazuryk, O., Filippov, V., \& Kitseliuk, V. (2020c). System Constructs for the Investment Security of a Country. Journal of Security and Sustainability Issues, 10(1), 345-358. https://doi.org/10.9770/jssi.2020.10.1(25)

Kwilinski, A., Shteingauz, D., \& Maslov, V. (2020d). Financial and Credit Instruments for Ensuring Effective Functioning of the Residential Real Estate Market. Financial and Credit Activities: Problems of Theory and Practice, 3(34), 133-140. Retrieved from https://fkd.ubs.edu.ua/index.php/fkd/article/view/3023

Kwilinski, A., Slatvitskaya, I., Dugar, T., Khodakivska, L., \& Derevyanko, B. (2020e). Main Effects of Mergers and Acquisitions in International Enterprise Activities. International Journal of Entrepreneurship, 24(Special Issue), 1-8. 
Kwilinski, A., Litvin, V., Kamchatova, E., Polusmiak, J., \& Mironova, D. (2021). Information Support of the Entrepreneurship Model Complex with the Application of Cloud Technologies. International Journal of Entrepreneurship, 25(1), 1-8.

Kyrylov Y, Hranovska V, Boiko V, Kwilinski A, \& Boiko L. (2020). International Tourism Development in the Context of Increasing Globalization Risks: On the Example of Ukraine's Integration into the Global Tourism Industry. Journal of Risk and Financial Management, 13(12), 303. https://doi.org/10.3390/jrfm13120303

Lai, K., Wong, C.W. (2012). Green logistics management and performance: Some empirical evidence from Chinese manufacturing exporters. Omega, 40(3), 267-282. https://doi.org/10.1016/j.omega.2012.07.002

Lakhno, V., Malyukov, V., Bochulia, T., Hipters, Z., Kwilinski, A., \& Tomashevska, O. (2018). Model of Managing of the Procedure of Mutual Financial Investing in Information Technologies and Smart City Systems. International Journal of Civil Engineering and Technology, 9(8), 1802-1812.

Lieder, M., Rashid, A. (2016). Towards circular economy implementation: A comprehensive review in context of manufacturing industry. Journal of Cleaner Production, 1, 36-51. https://doi.org/10.1016/j.jclepro.2015.12.042

Lyulyov, O., Us, Y., Pimonenko, T., Kwilinski, A., Vasylieva, T., Dalevska, N., Polcyn, J., \& Boiko, V. (2020a). The Link Between Economic Growth and Tourism: Covid-19 Impact. In Khalid S. Soliman (Ed.), Proceedings of the 36th International Business Information Management Association (IBIMA) 4-5 November 2020. (pp. 8070-8086). Granada, Spain: IBIMA Publishing.

Lyulyov, O., Pimonenko, T., Kwilinski, A., Us, Y., Arefieva, O., Akimov, O., \& Pudryk, D., (2020b). Government Policy on Macroeconomic Stability: Case for Low- and Middle- Income Economies. In Khalid S. Soliman (Ed.), Proceedings of the 36th International Business Information Management Association (IBIMA) 4-5 November 2020 (pp. 8087-8101). Granada, Spain: IBIMA Publishing.

Lyulyov, O., Pimonenko, T., Kwilinski, A., Dzwigol, H., Dzwigol-Barosz, M., Pavlyk, V., \& Barosz, P. (2021a). The Impact of the Government Policy on the Energy Efficient Gap: The Evidence from Ukraine. Energies, 14(2), 373. https://doi.org/10.3390/en14020373

Lyulyov, O., Pimonenko, T., Kwilinski, A., \& Us, Y. (2021b). The Heterogeneous Effect of Democracy, Economic and Political Globalisation on Renewable Energy. E3S Web of Conferences, 250, 03006. https://doi.org/10.1051/e3sconf/202125003006

Lyulyov, O., Vakulenko, I., Pimonenko, T., Kwilinski, A., Dzwigol, H., Dzwigol-Barosz, M. (2021c). Comprehensive Assessment of Smart Grids: Is There a Universal Approach? Energies, 14(12), 3497. https://doi.org/10.3390/en14123497

Mlaabdal, S., Chygryn, O., Kwilinski, A., Muzychuk, O., \& Akimov, O. (2020). Economic Growth and Oil Industry Development: Assessment of the Interaction of National Economy Indicators. In Khalid S. Soliman (Ed.), Proceedings of the 36th International Business Information Management Association (IBIMA) 4-5 November 2020 (pp. 8102-8114). Granada, Spain: IBIMA Publishing.

McKinnon, A., Browne, M., Whiteing, A., Piecyk, A. (2010). Green Logistics. Improving the Environmental Sustainability of Logistics. 3nd ed. London: Published by Kogan Page.

Mesjasz-Lech, A. (2011). Efektywnosc okonomiczna i sprawnosc ekologiczna logistyki zwrotnei. Czestochowa: Published by Technical University of Czestochowa, 43-46.

Mishenin, E., Koblyanskaya, I. (2017). Perspektivy i mekhanizmy razvitiya «Tsirkulyarnoy» ekonomiki $v$ globalnoy srede [Prospects and mechanisms of development of Circular 
economy in a global environment]. Marketing $i$ menedzhment innovatsiy, 2, 329343. (in Russian)

Miskiewicz, R. (2017a). Knowledge in the Process of Enterprise Acquisition. Progress in Economic Sciences, 4, 415-432. https://doi.org/10.14595/PES/04/029

Miskiewicz, R. (2017b). Knowledge Transfer in Merger and Acquisition Processes in the Metallurgical Industry. Warsaw: PWN.

Miskiewicz, R. (2018). The Importance of Knowledge Transfer on the Energy Market. Polityka Energetyczna, 21(2), 49-62. http://dx.doi.org/10.24425\%2F122774

Miskiewicz, R. (2019). Challenges Facing Management Practice in the Light of Industry 4.0: The Example of Poland. Virtual Economics, 2(2), 37-47. https://doi.org/10.34021/ve.2019.02.02(2)

Miskiewicz, R. (2020a). Internet of Things in Marketing: Bibliometric Analysis. Marketing and Management of Innovations, 3, 371-381. http://doi.org/10.21272/mmi.2020.3-27

Miskiewicz, R. (2020b). Efficiency of Electricity Production Technology from Post-Process Gas Heat: Ecological, Economic and Social Benefits. Energies, 13(22), 6106. https://doi.org/10.3390/en13226106

Miskiewicz, R. (2021a). Knolege and Innovation 4.0 Today's Electromobility. In Z. Makieła, M.M. Stuss, \& R. Borowiecki (Eds.), Sustainability, Technology and Innovation 4.0 (pp. 256-275). NY: Routledge.

Miśkiewicz, R. (2021b). The Impact of Innovation and Information Technology on Greenhouse Gas Emissions: A Case of the Visegrád Countries. Journal of Risk and Financial Management, 14(2), 59. https://doi.org/10.3390/jrfm14020059

Miśkiewicz, R, \& Wolniak, R. (2020). Practical Application of the Industry 4.0 Concept in a Steel Company. Sustainability, 12(14), 5776. https://doi.org/10.3390/su12145776

Müller, A., Wilts, H. (2019). Bestandsaufnahme für die erfolgreiche Planung und Umsetzung einer Kreislaufwirtschaft in Belarus. Eine Analyse von Stärken und Schwächen sowie von Chancen und Risiken im Gebiet Brest. Angefertigt vom Wuppertal Institut im Auftrag der Deutschen Gesellschaft für Internationale Zusammenarbeit (GIZ). Berlin.

Murray, A., Skene, K., Haynes, K. (2017). The circular economy: an interdisciplinary exploration of the concept and application in a global context. J. Bus. Ethics., 140(3), 369-380.

Pająk, K., Kamińska, B., \& Kvilinskyi, O. (2016). Modern Trends of Financial Sector Development under the Virtual Regionalization Conditions. Financial and Credit Activity: Problems of Theory and Practice, 2(21), 204-217. https://doi.org/10.18371/fcaptp.v2i21.91052

Pająk, K., Kvilinskyi, O., Fasiecka, O., \& Miskiewicz, R. (2017). Energy security in regional policy in Wielkopolska region of Poland. Economics and Environment, 2(61), 122-138.

Pearce, D., Markandya, A., Barbier, E. (1989). Blueprint for a Green economy. London: Earthscan Publications Ltd.

Pheifer, A. G. (2017). Barriers and Enablers to Circular Business Models. Brielle.

Polcyn, J. (2018). Human Development Level as a Modifier of Education Efficiency. Management, 22(2), 171-186. https://doi.org/10.2478/manment-2018-0030

Polcyn, J. (2021). Eco-Efficiency and Human Capital Efficiency: Example of Small- and Medium-Sized Family Farms in Selected European Countries. Sustainability, 13(15), 6846, https://doi.org/10.3390/su13126846 
Prokopenko, O., \& Miskiewicz, R. (2020). Perception of "Green Shipping" in the Contemporary Conditions. Entrepreneurship and Sustainability Issues, 8(2), 269-284. https://doi.org/10.9770/jesi.2020.8.2(16)

Reike, D., Vermeulen, W.J.V., Witjes, S. (2018). The circular economy: New or Refurbished as CE 3.0? - Exploring Controversies in the Conceptualization of the Circular Economy through a Focus on History and Resource Value Retention Options. Resources, Conservation and Recycling, 135, 246-264. https://doi.org/10.1016/j. resconrec.2017.08.027

Ritzén, S., Sandström, G. Ö. (2017). Barriers to the Circular Economy - integration of perspectives and domains. Procedia CIRP, 64, 7-12.

Rodrigue, J.-P., Slack, B., Comtois, C. (2001). Green Logistics (the Paradoxes of). The Handbook of Logistics and Supply Chain Management (pp. 339-350). London, Pergamon.

Saługa, P.W., Szczepańska-Woszczyna, K., Miśkiewicz, R., \& Chłąd, M. (2020). Cost of Equity of CoalFired Power Generation Projects in Poland: Its Importance for the Management of DecisionMaking Process. Energies. 13(18), 4833. https://doi.org/10.3390/en13184833

Sandiuk, H., Lushpiienko, Yu., Trushkina, N., Tkachenko, I., Kurganskaya, E. (2019). Special Procedures for Electronic Public Procurement. Journal of Legal, Ethical and Regulatory Issues, 22. Special Issue 2. Business laws and legal rights: research and practice. URL: Retrieved from https://www.abacademies.org/articles/special-procedures-for-electronic-public-procurement1544-0044-22-SI-2-351.pdf (accessed 14 May 2021).

Savchenko, T., Basiurkina, N., Rodina, O., \& Kwilinski, A. (2019). Improvement of the Assessment Methods of Product Competitiveness of the Specialized Poultry Enterprises. Management Theory and Studies for Rural Business and Infrastructure Development, 41(1), 43-61. https://doi.org/10.15544/mts.2019.05

Sauve, S., Bernard, S., Sloan, P. (2016). Environmental sciences, sustainable development and circular economy: alternative concepts for trans-disciplinary research. Environ., 17, 48-56. https://doi.org/10.1016/j.env-dev.2015.09.002

Sbihi, A., Eglese, R.W. (2009). Combinatorial optimization and Green Logistics. Annals of Operations Research, 175(1), 159-175. https://doi.org/ 10.1007/s10479-009-0651-z

Semashko, O. (2020). Save resources and make money. German expert on the chances of the circular economy of Belarus (interview with $\mathrm{H}$. Wiltz). October 13. Retrieved from https://zautra.by/news/sekonomit-resursy-i-zarabotat-nemetckii-ekspert-o-shansakh-kotoryedaet-tcirkuliarnaia-ekonomika-belarusi (accessed 24 May 2021). [in Russian]

Seroka-Stolka, O. (2014). The Development of Green Logistics for Implementation Sustainable Development Strategy in Companies. Procedia - Social and Behavioral Sciences, 151, 302-309. https://doi.org/10.1016/j.sbspro.2014.10.028

State Statistics Service of Ukraine (2020). Activity of business entities 2019: statistical yearbook. Kyiv.

State Statistics Service of Ukraine (2020). Environment of Ukraine 2019: statistical yearbook. Kyiv.

Su, B., Heshmati, A., Geng, Y., Yu, X. (2013). A review of the circular economy in China: Moving from rhetoric to implementation. J. Clean. Prod., 42, 215-227.

Tkachenko, V., Kwilinski, A., Korystin, O., Svyrydiuk, N., \& Tkachenko, I. (2019a). Assessment of Information Technologies Influence on Financial Security of Economy. Journal of Security and Sustainability, 8(3), 375-385. http://doi.org/10.9770/jssi.2019.8.3(7) 
Tkachenko, V., Kwilinski, A., Klymchuk, M., \& Tkachenko, I. (2019b). The Economic-Mathematical Development of Buildings Construction Model Optimization on the Basis of Digital Economy. Management Systems in Production Engineering, 27(2), 119-123. http://doi.org/10.1515/mspe2019-0020

Tkachenko, V., Kwilinski, A., Tkachenko, I., \& Puzyrova, P. (2019c). Theoretical and Methodical Approaches to the Definition of Marketing Risks Management Concept at Industrial Enterprises. Marketing and Management of Innovations, 2, 228-238. http://doi.org/10.21272/mmi.2019.220

Tkachenko, V., Kwilinski, A., Kaminska, B., Tkachenko, I., \& Puzyrova, P. (2019d). Development and Effectiveness of Financial Potential Management of Enterprises in Modern Conditions. Financial and Credit Activity: Problems of Theory and Practice, 3(30), 85-94. https://doi.org/10.18371/fcaptp.v3i30.179513

Tkachenko, V., Kuzior, A., \& Kwilinski, A. (2019e).Introduction of artificial intelligence tools into the training methods of entrepreneurship activities. Journal of Entrepreneurship Education, 22(6), 1-10.

Trąpczyński, P., Gorynia, M., Nowak, J., \& Wolniak, R. (2019). EU Countries from Central and Eastern Europe, and the Investment Development Path Model: A New Assessment. Argumenta Oeconomica, 2(43), 385-406. https://doi.org/10.15611/aoe.2019.2.16

Trushkina, N. (2018). Green logistics as a tool to improve the quality of life in conditions of globalization. Contemporary Problems of Improve Living Standards in a Globalized World: Volume of Scientific Papers (pp. 147-152). Opole, Publishing House WSZiA.

Trushkina, N. (2019). Development of the information economy under the conditions of global economic transformations: features, factors and prospects. Virtual Economics, 2(4), 7-25. https://doi.org/10.34021/ve.2019.02.04(1)

Trushkina, N. V. (2019a). Green logistics as a component of corporate social responsibility of business. III International Scientific Conference The Modern Trends in the Development of Business-Social Responsibility: Conference Proceedings, June 28th, 2019, Nova School of Business and Economics, Lisbon, Portugal (pp. 112-115). Riga: Baltija Publishing. [in Russian]

Trushkina, N., Abazov, R., Rynkevych, N., Bakhautdinova, G. (2020). Digital Transformation Organizational Culture under Conditions of the Information Economy. Virtual Economics, 3(1), 738. https://doi.org/10.34021/ve.2020.03.01(1)

Trushkina, N. (2020). International experience in implementing the mechanism of "green" financing for sustainable development of transport and logistics systems. Competitiveness and sustainable development: Book of abstracts of the 2nd Economic International Conference (pp. 10), Chisinau, Republic of Moldova, November 20th, 2020. Chişinău: Tehnica-UTM.

Tukker, A. (2015). Product services for a resource-efficient and circular economy - a review. J. Clean. Prod., 15, 76-91. https://doi.org/10.1016/j.jclepro.2013.11.049

Ubeda, S., Arcelus, F., Faulin, J. (2011). Green logistics at Eroski: A case study. International Journal of Production Economics, 131(1), 44-51. https://doi.org/10.1016/j.ijpe.2011.04.041

UNEP (2011). Towards a Green Economy: Pathways to Sustainable Development and Poverty Eradication - A Synthesis for Policy Makers. Retrieved from https://sustainabledevelopment.un.org/_content/documents/126GER_synthesis_en.pdf (accessed 17 May 2021). 
Wei, F., Liu, S., Yin, L., Li, W., Yu, Z. (2014). Research on Performance Evaluation System for Green Supply Chain Management Based on the Context of Recycled Economy-Taking Guangxi's Manufacturing Industry as Example. J. Grey Syst., 26, 177-187.

Wen, C. F., Zhao, Y. L., Liang, R. Z. (2007). Recycle of low chemical potential substance. Resources, Conservation and Recycling, 2, 475-486. https://doi.org/ 10.1016/j.resconrec.2006.10.011

Yuan, Z., Bi, J., Moriguichi, Y. (2006). The circular economy: A new development strategy in China. J. Ind. Ecol., 10, 4-8.

Zaloznova, Yu., Kwilinski, A., Trushkina, N. (2018). Reverse logistics in a system of the circular economy: Theoretical aspect. Economic Herald of the Donbas, 4(54), 29-37.

Zastempowski, M., Glabiszewski, W., Krukowski, K., \& Cyfert, S. (2020). Technological Innovation Capabilities of Small and Medium-Sized Enterprises. European Research Studies, 23(3), 460-474.

Zhang, H., Hara, K., Yabar, H., Yamaguchi, Y., Uwasu, M., Morioka, T. (2009). Comparative analysis of socio-economic and environmental performances for Chinese EIPs: Case studies in Baotou, Suzhou, and Shanghai. Sustainability Science, 4. 263-279. https://doi.org/10.1007/s11625-009-0078-0

Zhang, S., Lee, C., Chan, H., et al. (2015). Swarm intelligence applied in green logistics: A literature review. Engineering Applications of Artificial Intelligence, 37, 154-169. https://doi.org10.1016/j.engappai.2014.09.007

Zhu, Q., Geng, Y., Sarkis, J., Lai, K. (2011). Evaluating green supply chain management among Chinese manufacturers from the ecological modernization perspective. Transp. Res. PART E-LOGISTICS Transp., 47, 808-821. https://doi.org/10.1016/j.tre.2010.09.01 